\title{
A Political Ecology of Healing
}

\author{
Elisabeth Middleton ${ }^{1}$ \\ University of California, Davis, USA.
}

The concept of historical unresolved grief has powerful implications not only for healing from our past, but for giving us the strength and commitment to save ourselves and future generations.

Maria Yellow Horse Brave Heart and Lemrya DeBruyn ${ }^{2}$

\section{Introduction}

On June 29, 2004, the Pacific and Watershed Lands Stewardship Council convened a public meeting in Chester, California, in the northeastern Sierra Nevada mountains. The Board members and staff introduced the Council's purpose - to oversee the planning and divestiture of approximately 140,000 acres (56,656 ha.) of former Pacific Gas \& Electric Company land around California-and then opened the floor to public comments and suggestions. One after another, representatives from Mountain Maidu groups including the Honey Lake Maidu, the Roundhouse Council Indian Education Center, and the Maidu Cultural and Development Group, and their allies, stood up and requested the formal inclusion of a Native American representative on the Stewardship Council Board. All of the lands to be divested, and, particularly for Maidu participants, much of the 53,185 acres (21,523 ha.) within the Feather River Planning Unit lie within the Mountain Maidu homeland. To not have an official representative of Native American interests on the Board to oversee the planning efforts for these lands seemed to indicate a blatant disregard for the historical and contemporary Native presence.

In his 1998 review of political ecology, political geographer Raymond Bryant argues that, in order to understand politicized environments, one must take a historical perspective:

The intervention of the European and American colonial powers in the 'third-world' is especially crucial to understanding contemporary patterns of human-environmental interaction and associated power relations...the colonial legacy is alive and well in many parts of the third-world today... ${ }^{3}$

This article argues that this legacy also remains particularly important in fourth world communities within first world nations, as the above example shows indigenous people confronting American conservation policies. While the Stewardship Council acted quickly to add a representative to their Board that could argue for Native American interests throughout the State, the struggle continues for Maidu groups working to organize and present a unified plan to the Council. Plans from indigenous coalitions such as the Maidu Summit must compete with the plans submitted by established conservation non-profit organizations and Federal conservation agencies that are well-placed to meet the six Beneficial Public Values for each parcel, as defined by the Council with public input. ${ }^{4}$ I will return to the Council and the Maidu Summit, one of the Maidu groups submitting an application for lands to the Council throughout this article.

Theoretically, this article introduces two more important bodies of theory, from Latin American and indigenous scholars, respectively, to the political ecology toolkit. Following Michael Watts' call for further research in the arena of environment and rights, I see a specific need for theories addressing coloniality in

\footnotetext{
${ }^{1}$ Beth Rose Middleton, Assistant Professor, Dept. of Native American Studies, University of California, Davis, USA. brmiddleton "at" ucdavis.edu. I gratefully acknowledge the time and insights of my colleagues and mentors, including all Maidu Summit members and participants; Louise Fortmann, Jeff Romm, Ramón Grosfoguel, and Leonard Duhl at UC Berkeley; and Ben Orlove at UC Davis. Funding from the NSF Graduate Research Fellowships, Community Forestry and Environmental Research Partnerships, and UC Berkeley Chancellor's Opportunity Fellowship supported this work. I thank the 2009 Eric Wolf Prize committee members for fruitful suggestions. All errors and shortcomings remain my own. This paper was awarded the Eric Wolf Prize, Political Ecology Society, 2009.

${ }^{2}$ Brave Heart, M.Y.H., and L. DeBruyn. "The American Indian Holocaust: Healing Historical Unresolved Grief." American Indian and Alaska Native Mental Health Research. Monograph series 8:2. 1998.

${ }^{3}$ Bryant, R. "Power, knowledge and political ecology in the third world: a review." Progress in Physical Geography 22 (1): 79-94. 1998: p85.

${ }^{4}$ According to the Stewardship Council Land Conservation Plan, "Appendix E of the Settlement Agreement [between Pacific Gas and Electric and the California Public Utilities Commission] requires PG\&E to ensure that the Watershed Lands are conserved for the following broad range of beneficial public values: (1) protection of the natural habitat of fish, wildlife, and plants; (2) preservation of open space; (3) outdoor recreation by the general public; (4) sustainable forestry; (5) agricultural uses; and (6) historic values. The Stewardship Council was created to ensure this commitment was realized through the development and implementation of land conservation recommendations consistent with this mandate." Stewardship Council Board of Directors. Land Conservation Plan. Volume 1: Section 2-1. 2007. Available at http://lcp.stewardshipcouncil.org. Site accessed December 15, 2008.
} 
its multiple manifestations within the first world. ${ }^{5}$ Political ecology has examined how communities negotiate resource claims within a globalized political-economic context, linking grounded understanding of community, place, and political economy to larger cultural processes facing historically colonized communities. ${ }^{\circ}$ However, there has been less guidance within the field about how to research this in a first world, neo-colonial context. Distinct from colonialism, which can be limited in time and space, coloniality refers to the ways in which the political, epistemic, racial, and cultural hierarchies that were set in place during the colonial era remain entrenched in power relations and subjectivities:

...coloniality survives colonialism. It is maintained alive in books, in the criteria for academic performance, in cultural patterns, in common sense, in the self-image of peoples, in aspirations of self, and so many other aspects of our modern experience. In a way, as modern subjects we breathe coloniality all the time and everyday. ${ }^{7}$

This is not a disempowering, victimized perspective, focused simply on colonialism and its ongoing manifestations. Rather, it is a stance of liberation: recognizing coloniality acknowledges the entrenched subtleties of colonialism that linger in both formerly colonized and colonizer societies, and this acknowledgement offers a pathway toward the conscious development of de-colonial institutions and ideas.

Since political ecology already has an "everything but the kitchen sink" reputation, according to Piers Blaikie's review, why bring in new streams of thought? ${ }^{8}$ While the political ecology approach has increased our understanding of the relationships between resource control and governance, for example, it has not yet deeply engaged with ethnic studies. I argue that one cannot understand human-environment interactions within formerly colonized communities without both an explicit examination of coloniality from critical ethnic studies; and analyses from third and fourth world scholars of their experiences of coloniality at multiple scales. ${ }^{9}$

\section{The Maidu context}

The great Maidu "nation," is one of the largest Native Indian tribes in California, whether we organize people based on Kroeber's linguistic boundaries (which would include the Nisenan and Concow Maidu), or around the nationalistic views of some Maidu. ${ }^{10}$ Yet, the Maidu Nation is difficult to find-on a map, in the list of recognized California tribes, or in the Census (see Fig. 1). This invisibility stems from treaties made with Maidu in 1851, and "lost" in the Senate archives for 50 years in response to pressure from land

\footnotetext{
${ }^{5}$ Watts, M.J. "Political Ecology," in T. Barnes and E. Sheppard (eds.) A Companion to Economic Geography. Blackwell: Oxford. 2000: 271.

${ }^{6}$ See, for example, Gezon's description of the role of historical relationships and ritual in shrimp farming in northern Madagascar, in a context of increasing global demand for shrimp. Gezon, Lisa. "Of Shrimps and Spirit Possession." American Anthropologist 101(1): 48-67. March, 1999.

${ }^{7}$ N. Maldonado-Torres 2007: 243.

${ }^{8}$ As first articulated by Piers Blaikie (Blaikie, P. The Political Economy of Soil Erosion in Developing Countries. Longman: London. 1985) and Blaikie and Brookfield, (Blaikie, P., and H. Brookfield. Land Degradation and Society. Longman: London. 1987) political ecology is an intervention to illuminate the complex relationships between social, political, and economic forces and multiple scales (household to global) that influence and are influenced by ecological factors. Blaikie (1985), in particular, interrogated the concept of soil erosion as an issue of environmental degradation borne of political-economic relations at multiple scales. See Blaikie, P. "A Review of Political Ecology." Zeitschrift fur Wirtschaftsgeographie. Jg. 43 (1999).

9 Peruvian sociologist Anibal Quijano is credited with the notion of the "coloniality of power," (Quijano, A. "Coloniality of Power, Eurocentrism, and Latin America." Nepantla 1(3): 533-80. 2000). Quijano published the concept earlier in Spanish (see, for example Quijano, A. "Colonialidad y modernidad-Racionalidad," and "Colonialidad del poder" in H. Bonilla, comp. (Bogotá Tercer Mundo Editores), Los Conquistados: 1492 y la Población Indígena de las Américas. 1992: 437-47.) Several scholars have expanded on Quijano's coloniality, including Ramón Grosfoguel, with his explanation of the entangled heterarchy that manifests coloniality (Grosfoguel, R. "The Epistemic Decolonial Turn." Cultural Studies 21(2): 211-223. 2007); Walter Mignolo, with his integration of the concepts of coloniality, modernity, and decolonizing knowledge-particularly as regards space and history (Mignolo, W. "Delinking: the rhetoric of modernity, the logic of coloniality, and the grammar of de-coloniality." Cultural Studies. 21(2): 449-514. 2007); and Nelson Maldonado-Torres' Fanonian exploration of the coloniality of being and its dehumanizing consequences (Maldonado-Torres, N. "On the Coloniality of Being." Cultural Studies 21(2): 240 -270. 2007.)

${ }^{10}$ For a map of California linguistic boundaries, see Kroeber, A., Handbook of the Indians of California. Washington, D.C: Bureau of American Ethnology Bulletin No. 78. 1925; and the summary of linguistic classification in California by Heizer, R. Languages, Territories, and Names of California Indian Tribes. UC Press: Berkeley. 1966. For example, as one Maidu interviewee explained to me, "The government eliminated Tribes by only recognizing the rancherias as Tribes. Once we were a nation. Now we have dwindled down to almost nothing." Interviewee C3. Personal communication. January 12, 2006.
} 
speculators that California was "too valuable" to give 8,800,000 acres (3,561,234 ha.) to the Indians. ${ }^{11}$ The non-ratification of these treaties left Maidu officially landless and federally unrecognized as a tribe.

\section{Yamanim Maiduk Kodo}

(General Map of the Mountain Maidu Homeland)

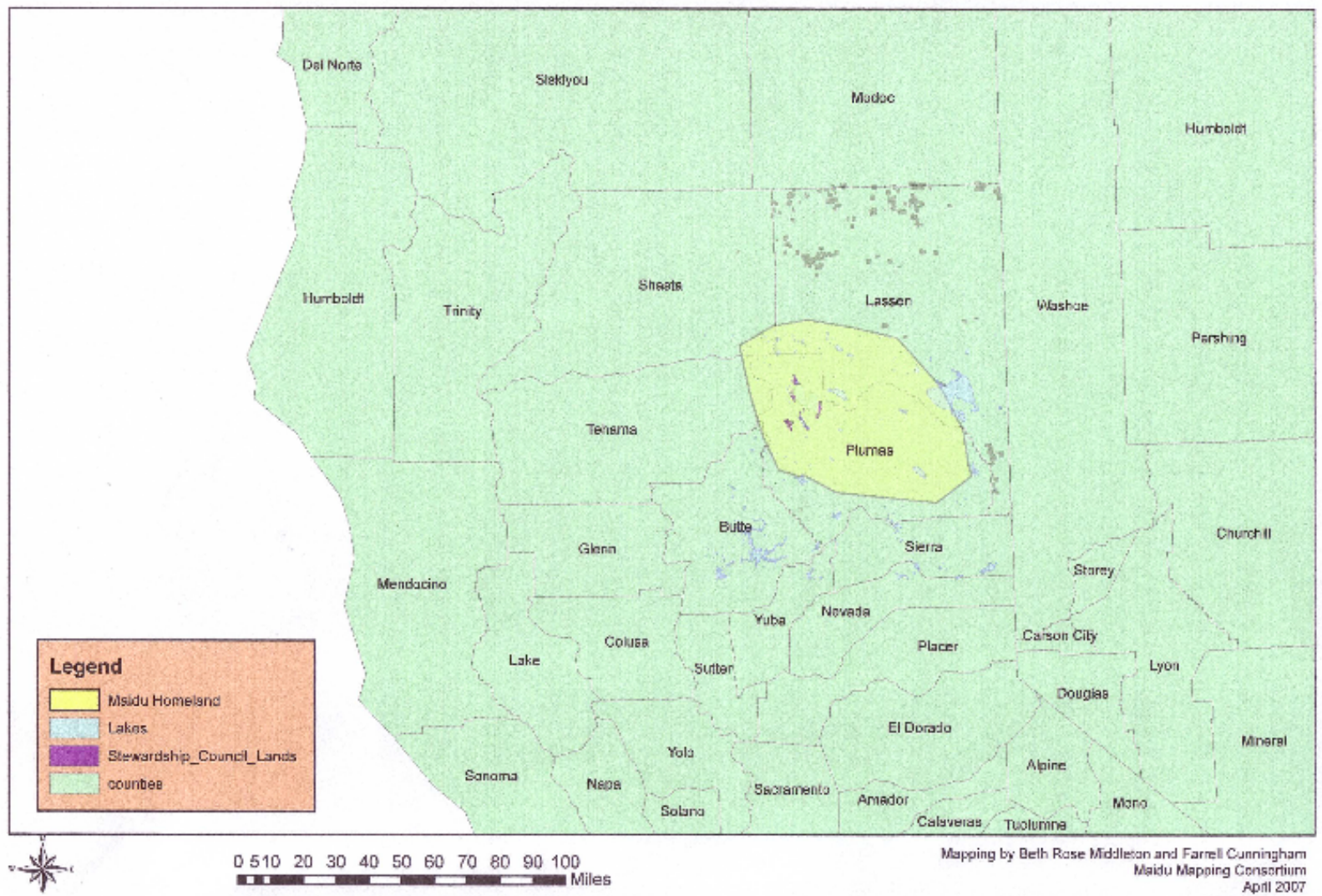

Fig. 1. Map of Mountain Maidu Homeland, Northern California, USA. Source: author and Farrel Cunningham, 2007.

Maidu were not able to access collective Indian lands until a series of appropriations beginning in 1914 (38 Stat. 582-589) and culminating in the 1922 "Purchase of Land for homeless Indians of California" (42 Stat. 559-567), authorized funds for land purchase. ${ }^{12}$ These Appropriations and Bills enabled the purchase of the Taylorsville and Susanville Rancherias in 1923 and 1924 respectively. Greenville Rancheria, in contrast, was the site of the Greenville Indian Industrial Training School, which was established by a combination of purchase and executive order between 1897 and $1902 .{ }^{13}$ After the school burned down in 1921, a Department of the Interior representative explained the status of the land:

\footnotetext{
${ }^{11}$ Hoopes, C. Domesticate or Exterminate: California Indian Treaties Unratified and Made Secret in 1852. Redwood Coast Publications. 1975. A letter dated February 20, 1948 to Senator Hugh Butler, Chairman, Committee on Interior and Insular Affairs, from Assistant Secretary of the Interior William E. Warne, US Department of the Interior, notes that "Under the 18 unratified treaties of 1852 the California Indians, signatories of these treaties, were promised 8,800,000 acres." Slagle, Al Logan. Collection. D-437. University of California, Davis. Shields Library, Department of Special Collections. Box 45.

12 In 1923, the California State Assembly also passed A.B. 1333 to set aside 1,488 lands for the tribes in Plumas, Lassen, and Modoc Counties.

13 The initial 40 acres was purchased from a private owner in 1897, then a former Indian allotment of 160 acres was acquired by Executive Order on November 26, 1902, and a final 75 acres was purchased from Antone and Eleanor Schieser in 1916. Giles-Rankin, J. E. An Ethnohistorical Reconstruction of the Greenville Indian Industrial School. Master's Thesis: California State University, Chico. 1983.
} 
...the Greenville Rancheria does not belong to any named Indians... It belongs to the United States and unlike most of the other rancherias in California, it was not originally bought as a homesite for landless Indians; it was set aside for school purposes. When it was no longer used as a school site, the Government allowed the Indians in the area to move onto the land and live there. ${ }^{14}$

As such, the Greenville School site was eventually treated as a rancheria, and subject to the termination process initiated by House Concurrent Resolution 108 (1954), which granted Indians "all of the rights and prerogatives pertaining to American citizenship" by "freeing them from Federal supervision and control."15 The California Rancheria Act, authorized by Public Law 85-671 on August 18, 1958, and implemented between 1961 and 1970, resulted in the termination of 61 tribes and bands in California. Greenville Rancheria's specific plan for dissolution was approved on September 4, 1959 by the Commissioner of Indian Affairs, and finalized on April 11, 1960. ${ }^{16}$

Joe Myers (Pomo), attorney and founder of the National Indian Justice Center describes the termination plans as contracts, in which the Bureau of Indian Affairs (BIA) promised infrastructure like roads, sewers, and water to tribal members, who were also given title to their houses and land. ${ }^{17}$ Termination ended the government-to-government relationship between tribes and the Federal government, ending tribal sovereignty, and divesting people of their official status as Indians. In a landmark 1983 case, Tillie Hardwick (Pomo) represented seventeen terminated California rancherias (including Greenville Rancheria) against the United States for violating these contracts. ${ }^{18}$ Each of these tribes could prove that the government had never lived up to its side of the termination bargain by providing improved water, roads, and sewage infrastructure. The U.S. District Court of the Northern District of California determined that the government had breached its trust obligation, and each of the 17 rancherias was restored to Federal recognition.

As contemporary tribal entities, however, the rancherias may or may not represent the entire local Native population. Following judicial precedent that the Federal government cannot interfere in tribal membership decisions, tribal membership criteria are determined internally by tribal membership, tribal government, and formal enrollment ordinances. ${ }^{19}$ Following the reinstatement of the Greenville Rancheria in 1983, for example, the tribal leadership followed a Bureau of Indian Affairs recommendation to restrict membership to those where were physically present on the rancheria at the time of termination. ${ }^{20}$ This resulted in a base roll of 10 members that, with their descendents, has grown to approximately 144 members by $2009 .^{21}$

${ }^{14}$ Letter from the U.S. Department of the Interior (no name) to Herbert Young, dated March 25, 1960. Greenville; Central California Agency; Records of the Bureau of Indian Affairs; Record Group 75; National Archives, Pacific Region [San Francisco], San Bruno, California.

${ }^{15}$ Getches, D. H., C. F. Wilkinson, and R. A. Williams, Jr. Cases and Materials on Federal Indian Law. West Group: St. Paul, Minnesota. 1988: 205-06.

${ }^{16}$ The California Rancheria Act called for the termination of 44 rancherias. Public Law 85-671, August 18, 1958 | [H. R. 2824] 72 Stat. 619. See, for example, letter from Deputy Commissioner of Indian Affairs H. Rex Lee to Representative Harold T. Johnson. April 3, 1961. Records of the Bureau of Indian Affairs; Record Group 75; National Archives: Washington, D.C.

${ }^{17}$ Myers, J. Personal communication: Berkeley, California. October, 2003.

${ }^{18}$ Tillie Hardwick et al. v. United States, Civil No. C-79-1910-SW (N.D. Cal. 1983).

19 The 1978 Supreme Court case Santa Clara Pueblo v. Martinez (436 U.S. 49, 98 S.Ct. 1670, 56 L.Ed.2d 106) prohibited the court from intervening in a tribal membership decision. In this case, a female member of the Santa Clara Pueblo, and a resident of the Santa Clara reservation, married a Navajo male. Because her husband was not a member of the Pueblo, their children were not enable to enroll, to remain on the Pueblo after their mother's death, or to inherit her home and property. The Court affirmed the Pueblo's right to make membership decisions based upon its cultural norms.

An example of an enrollment ordinance is available from the Greenville Rancheria, which defines the Base Membership Role as follows: "The people listed on the Plan for Distribution of Assets of the Greenville Rancheria approved by the Secretary of the Interior on March 25, 1960, pursuant to the California Rancheria Act of August 18, 1958, as amended." The Greenville Rancheria Enrollment Ordinance is online at http://www.greenvillerancheria.com/pdf/Enrollment\%20Ordinance.pdf. Site last accessed May 14, 2009.

${ }^{20}$ Interviewee B1, for example, explained, "...they had an election for the permanent council, and to approve the constitution, and [the elected chair]...eliminated all but distributees. He went to the BIA for advice and training....and they told him to draw back to the originals and then adopt others..." Personal communication. January 17, 2006. As Interviewee C3 described, "Membership is seen as an internal affair of the tribe. But the BIA did interfere by telling them only lineals could be members. We asked lineals if they wanted to open the membership, they did, but the BIA would only recognize lineals..." Personal communication. January 13, 2005.

${ }^{21}$ This was the 1994 population, as reported in Tiller, Veronica E. Velarde. Tiller's Guide to Indian Country. BowArrow Publishing Company. Albuquerque: New Mexico. 1996. The population of 144 is also listed on the San Diego State University online dictionary of "California Indians and Their Reservations," available at http://infodome.sdsu.edu/research/guides/calindians/calinddictdl.shtml. Site last accessed May 14, 2009. 
According to the 2000 Census, the surrounding area includes at least 530 people reporting Native American as their sole ethnicity. ${ }^{22}$ However, the Census is a problematic source of information on the Maidu population because there may be Maidu who count themselves as mixed race or who do not report their ethnicity, and there are other Native American people included in the category of "Native American," which is not broken down by tribal affiliation. At the November 2008 Maidu Summit meeting, one participant reported that there were as many as 1,500 Maidu heads of household in Plumas County. ${ }^{23}$ Of the Maidu population, some are members of other rancherias, but many are federally unrecognized and have no tribal membership, despite their related-ness to members of the recognized tribes. Because of this lack of collective recognition, Maidu struggle to continue their land-based culture on the political, economic, and ecological margins of their own homeland.

\section{The Maidu Summit and the Pacific Watershed and Lands Stewardship Council}

Periodic opportunities have emerged for Maidu to gain access to alienated portions of their ancestral lands. The Pacific Watershed and Lands Stewardship Council, with its divestiture of PG\&E parcels throughout Maidu country, represents one such opportunity. In this section, I will sketch the trajectory of events that led to the establishment of the Council.

Stage 1. Lands and Context

In 1900, Big Meadows was still 25,000 acres (10,117 ha) of meadow and timber, irrigated by numerous springs and creeks, and crossed by the north fork of the Feather River. Leaving Big Meadows, the River dropped 4,350 feet $(1,326 \mathrm{~m})$ in seventy-four miles $(119 \mathrm{~km})$ down a canyon into Oroville, California. Three metropolitan investors and a young engineer saw opportunities for power development, and announced plans for hydroelectric facilities in Big Meadows, Butt Valley, and Humbug Valley in 1901. ${ }^{24}$ In 1902 they formed Great Western Power Company. Big Meadows was already under the ownership of private ranchers and Maidu allottees, so they had to first condemn, purchase, and otherwise acquire the lands. ${ }^{25}$ As early as 1922, total gross revenues to Great Western Power Company were US\$7.2 million, with the majority coming from electric energy generation and sales. ${ }^{26}$ The Maidu occupants of Big Meadows, Butt Valley and the Feather River Canyon saw none of this revenue, and instead suffered ongoing displacement; depletion and elimination of plant, riparian, and other resources; and mass destruction of their cultural sites, including the flooding of resource procurement areas and cemeteries.

In September 1925, North American Power Company purchased Great Western Power, along with San Joaquin Light and Power and other subsidiaries of Western Power Corporation. The enlargement of the Big Meadows/ Almanor dam proceeded, and was completed in 1927. In March 1928, Great Western completed the Chester Causeway across the upper end of Lake Almanor. In June 1930, Pacific Gas and Electric (PG\&E) acquired all of North American Power Company's holdings in California, including Great Western Power.

PG\&E is now one of California's largest landowners, with a long history of resource development in the Sierra Nevada. According to Nicholas Valey's History of the Feather River Canyon, PG\&E's hydroelectric generation system was "the world's largest privately owned utility system."27 A current PG\&E timeline, entitled "150 years of growth and change," notes that the company owns 68 powerhouses and 174 dams throughout California. ${ }^{28}$ The majority of these facilities harness water flowing from the Sierra Nevada Mountains to generate electricity used in homes and businesses in the Central Valley and California's coastal and southern metropolitan areas. The California Public Utilities Commission (CPUC), a consumer advocate and watchdog over private telecommunications, utility, water, railroad, and public transportation companies, regulates PG\&E.

In the late 1990s, California's largest private utilities (PG\&E and Southern California Edison) underwent utility de-regulation, divesting themselves of their power- generating facilities and purchasing electricity wholesale. De-regulation was unsuccessful: PG\&E and Southern California Edison found themselves paying high prices for electricity that was not always available, yet unable to raise citizen's rates to keep up with wholesale prices. ${ }^{29}$

\footnotetext{
${ }^{22}$ Plumas County: Race and Ethnicity. Census 2000. See http://www.Census.gov. Web site accessed June 1, 2008.

${ }^{23}$ Personal communication: Greenville, CA. November 16, 2008.

${ }^{24}$ Landon, M. N. Resource Development in the Feather River Basin: The Creation of Lake Almanor. California State University, Sacramento: Masters Thesis. 1988.

25 "Biggest Power Plant in World for Plumas County." Plumas National Bulletin. Vol. 45, No. 96: July 27, 1911.

${ }^{26}$ Great Western Power. Annual Report to Stockholders. 1922.

${ }^{27}$ Valey, N. N. History of Feather River Canyon. February 14, 1986.

${ }^{28}$ PG\&E Corporation Web site at http://www.pgecorp.com/150 Site accessed April, 2009.

${ }^{29}$ See, for example, Borenstein, S. "The Trouble with Electricity Markets: Understanding California's Restructuring Disaster." Journal of Economic Perspectives. 16(1): 191-211. Winter 2002.
} 
In 1999, PG\&E proposed selling 140,000 acres (56,656 ha) of land associated with their hydroelectric facilities to re-coup some of their lost revenue. PG\&E filed for bankruptcy in 2001, and, as part of the 2003 Settlement Agreement with the CPUC, the 140,000 acres of land were to be placed into protective management, under the oversight of the Stewardship Council. ${ }^{30}$ Originally named the PG\&E Environmental Enhancement Corporation (EEC), the Council is charged with creating land management plans, and transferring the lands to entities capable of implementation. Of this acreage, 38,094 acres $(15,416$ ha) are located in Plumas County (and include important Maidu sites such as Humbug Valley, and the lands surrounding Lake Almanor/ Big Meadows, Mountain Meadows, and Butt Valley).

According to the Settlement Agreement between the CPUC and PG\&E, membership of the Stewardship Council governing board would include representatives from PG\&E, the CPUC, the California Department of Fish and Game, the State Water Resources Control Board, the California Farm Bureau Federation, and three public members named by the CPUC. In response to comments on the structure of the Council, membership was augmented to include a representative from the California Resources Agency, the Central Valley Regional Water Quality Control Board, the Association of California Water Agencies, the Regional Council of Rural Counties, the California Hydropower Reform Coalition, the Trust for Public Land, the Office of Ratepayer Advocates, the California Forestry Association, and a joint liaison from the Federal Department of Agriculture-Forest Service and Department of Interior- Bureau of Land Management. According to the Settlement Agreement, "This board ensures that all of the key constituencies are represented in the development and implementation of the land conservation plan." ${ }^{31}$ As the Introduction shows, however, obviously the membership of the Board was not fully inclusive, and the Council was asked by the public to add a representative of Native American interests. In response, the Council invited Larry Myers (Pomo), Executive Secretary of the Native American Heritage Commission, to join the Board. In 2008, the Council also elected Ken Tipon (Pomo) to serve as an alternate for Myers.

\section{Stage 2. The Maidu Summit}

The Maidu Summit was initiated in 2003 in response to increased national homeland security concerns following the attacks of September 11, 2001. Noting the need for Maidu homeland security, the Maidu Cultural and Development Group (MCDG) and Susanville Indian Rancheria convened a Summit of Maidu groups, including non-profit organizations, unincorporated community groups, federally recognized rancherias, and petitioning Aboriginal tribal governments. ${ }^{32}$ The nine member organizations are Greenville Rancheria, a recognized tribal government in Plumas County; Maidu Cultural and Development Group, a non-profit organization with a mission to "research, preserve, and perpetuate the Maidu culture;" ${ }^{33}$ Maiduk Weye, a grassroots advocacy and education organization; Mountain Maidu Preservation Association, a grassroots organization working to protect and maintain Maidu cultural sites and cemeteries; Roundhouse Council, an Indian Education Center located in Greenville; Susanville Indian Rancheria, a federally recognized tribal government in Lassen County; Tasmam Koyom Cultural Foundation, a non-profit organization focused on the protection, maintenance, and cultural vitality of Humbug Valley; Tsi-Akim Maidu, a Maidu rancheria petitioning for Federal recognition based on the illegal condemnation and sale of Taylorsville Rancheria; and the United Maidu Nation, a petitioning Maidu government.

The Summit links active, contemporary cultural preservation with resource management, as members convene against a history of attempted genocide to re-assert their ties to place, culture, and one another. Since its formation, the Summit created a 10-point resolution to protect Homer Lake, a site used for training traditional doctors. The resolution called for the Lassen National Forest to block vehicular access to the site, and, in 2005, the Lassen National Forest responded by erecting road barriers. Summit participants also worked with other groups to oppose the construction of a thermal curtain in Lake Almanor that would threaten Maidu burials. ${ }^{34}$ In summer 2006, Summit members passed a resolution to seek lands from the Stewardship Council as restitution for the ongoing cultural disruption posed by hydroelectric development. As the 2007 Maidu Summit Land Management Plan Proposal to the Council reads:

30 California Public Utilities Commission. "Stipulation Resolving Issues Regarding the Land Conservation Commitment." September 25, 2003; and California Public Utilities Commission. "Opinion Modifying the Proposed Settlement Agreement of PG\&E Company, PG\&E Corporation, and the Commission Staff, and Approving the Modified Settlement Agreement." December 18, 2003.

31 "Opinion Modifying the Proposed Settlement Agreement of PG\&E Company, PG\&E Corporation and the Commission Staff, and Approving the Modified Settlement Agreement." Decision 03-12-035. December 18, 2003, before the Public Utilities Commission of the State of California. Available at http://www.stewardshipcouncil.org. Site accessed June 10, 2008.

${ }^{32}$ The primary partners in this effort were Farrell Cunningham, Marvena Harris, and Allen Lowry. The three of them talked to Maidu throughout the area to convene people to address site protection and cultural resources concerns.

${ }^{33}$ Excerpt from Maidu Cultural and Development Group mission statement, on file with author.

${ }^{34}$ See, for example, West, M. K., "Indian Rancheria says that curtain will destroy heritage" and "Thermal Curtain Breaks Graves Law, Says Rancheria." Feather River Bulletin, August 17, 2005. 
The Maidu Summit envisions these lands as a sort of vast and unique park dedicated to the purposes of education, healing, and ecosystem management based upon the Maidu cultural and philosophic perspectives as expressed through traditional ecology. These goals are achieved through the use of these lands as places for the demonstration of Maidu traditional ecology and for the perpetuation of the unique culture from which that traditional ecology was derived. We also envision these lands as an opportunity for education about social justice through their use to demonstrate a process toward building greater social harmony and the on-the-ground application of the idea of 'celebrating cultural diversity' through real empowerment of a minority cultural population. Healing can begin through the process of righting past wrongs. The healing will be on the part of the Maidu who can begin to rebuild their cultural lives and on the part of society in general through restoration of faith in national ideals and the basic enactment of justice. ${ }^{35}$

Summit members meet monthly to discuss Summit governance, cultural resource protection priorities, and the process of re-acquiring these lands.

The Summit shows Maidu asserting their rights to inclusive, united, self-governance, despite the Federal recognition of some community members and not others. Because of its potential to unite Mountain Maidu groups and organizations, including federally recognized and un-federally recognized people, the Summit can be extremely powerful-both ideologically and politically. ${ }^{36}$ However, because of the forces against it-for example, longstanding disagreements between families; internal turnover in tribal governments with representatives participating in the Summit; and fiscal and other incentives to concentrate power in the hands of recognized tribes - the Summit represents a struggle to break patterns of division in the community. The Summit is currently working to form a governance structure that enables broad inclusion and balanced representation of all members, while it also meets state non-profit law.

\section{Intergenerational trauma and healing}

The historic and contemporary configuration of governance and resource access in Maidu country exemplify the concept of intergenerational trauma, or the reproduction and accumulation of traumatic experiences across generations. Political ecologists such as Bryant and Peluso remind us that control and resistance are inscribed in the environment and in institutions of environmental governance. ${ }^{37}$ All groups are subject to regulations upon their access to the environment, but the historically violent way in which Maidu were separated from free access to their homeland, and the way in which this separation is reinforced by institutions today, results in trauma. This trauma manifests, in part, in the lack of Maidu access to their environment, and in the condition of the environment without Maidu stewardship. ${ }^{38}$

Eduardo Duran, who has worked as a counselor with Native populations for the last 30 years, and Bonnie Duran, go systematically through several periods of colonization-first contact, economic competition, invasion war, reservation, boarding school, and forced relocation and termination, to describe the internalization in Native individuals and communities of over a century of dehumanizing policies. ${ }^{39}$ One decade after this initial explanation, Eduardo Duran introduced the related, yet distinct, phenomenon of "soul wound," which situates this trauma on a spiritual level:

I was able to locate some wise elders who described the soul wounding process. They explained that the ancestral wounding that occurred in the community was being passed down through the generations. They gave accounts of how the genocide had occurred in their area. Between the years 1870 to 1900 , at least $80 \%$ of the population had been systematically exterminated. In

\footnotetext{
${ }^{35}$ Cunningham, F. Maidu Summit Land Management Plan Proposal and Working Document for the Pacific Forest and Watershed Lands Stewardship Council. July 2007.

${ }^{36}$ At least three Maidu (Farrell, in his review my dissertation, and Elder Fred "Coyote" Downey, and Don Ryberg, in their review of other documents) encouraged me not to use this terminology of "federally recognized" and "un-federally recognized," because to use the terms lends credence to the government's divisive and irrational system of recognizing some Maidu (and Native Americans in general, as this situation is repeated around California and the nation).

${ }^{37}$ R. Bryant 1998 and Peluso, N. L. Rich Forests, Poor People: Resource Control and Resistance in Java. University of California Press: Berkeley, CA. 1994.

${ }^{38}$ Maidu including Farrell Cunningham and Lorena Gorbet spoke of the importance of traditional stewardship to maintain a healthy ecosystem. In an article describing the Maidu Stewardship Project's reintroduction of traditional land management to US Forest Service land outside of Greenville, Gorbet "... remembers walking past these trees five years ago, when the land 'felt gray and sad.' Today the plants are coming back. The land is responding." Little, J. B. "Maidu Indians Work to Restore their Land and Culture". American News Service. July 20, 2000. http://www.berkshirepublishing.com/ans/HTMView.asp?parItem=S031000558A. Site accessed December 14, 2008. In a piece detailing the thoughts underlying traditional management, Cunningham wrote, "It is believed that good thoughts will be absorbed by the plant being interacted with causing the plant to grow better and the resulting product to be more nourishing..." Cunningham, F. "Traditional Ecology," in Feather River Country. Forthcoming.

${ }^{39}$ Duran, E., and B. Duran. Native American Postcolonial Psychology. State University of New York Press. 1995.
} 
addition, they explained how the earth had been wounded and how, when the earth is wounded, the people who are caretakers of the earth are also wounded at a very deep soul level. ${ }^{40}$

Maria Yellow Horse Brave Heart (Lakota), a historical trauma specialist, similarly examines the wounding of Native people, and its exacerbation by the lack of general acknowledgement of American Indian genocide. This lack of acknowledgement has resulted, in part, in unresolved grief among Native individuals and communities. ${ }^{41}$ The founder of the Takini Network, a non-profit organization focused on helping indigenous communities recognize and heal from intergenerational trauma and historically unresolved grief, Brave Heart has worked to develop a healing model to address trauma at individual, community, and tribal/national scales. ${ }^{42}$ The model follows a series of steps, in which individuals and groups confront the historical trauma, understand it, release the pain through traditional ceremonies, and, ultimately, move beyond the trauma. ${ }^{43}$

Maidu activist interventions such as the Summit have attempted to counter multiple, intergenerational, natural resource-related manifestations of trauma and wounding. ${ }^{44}$ This trauma manifests as lack of access to sacred sites, an inability to protect sacred sites and burials, a lack of access to gathering sites and ceremonial sites, a lack of access to hunting areas or to hunting and fishing permits, and an inability to steward the landscape and thereby maintain living cultural relationships with the land. ${ }^{45}$ According to the Italian revolutionary thinker Antonio Gramsci, even as hegemonic forces deny Maidu access to resources, within that hegemony there are always elements of resistance. ${ }^{46}$ Efforts to de-colonize institutions disrupt the conditions that perpetuate intergenerational trauma, thereby enabling a re-organization of resources and political economy. Maidu activism works to counter trauma by de-colonizing institutions, knowledge, and practices, and by maintaining and expanding community and ceremonial efforts to heal.

Drawing on the insights of Maidu community members, Duran, and Brave Heart and DeBruyn, "healing" in the Maidu community includes ceremonies; external and internal acknowledgement of trauma; and actual recovery of lands and re-claiming of institutions. ${ }^{47}$ I focus on new Maidu forms of organization that explicitly link identity and land, and resist Federal and state control, such as the Maidu Summit. The Summit is de-colonial in that it pushes against external incentives to remain divided, for example, by affirming one federally recognized rancheria as the only representative of the Tribe. It also may be called "healing," building on the contributions of indigeneity scholars and trauma-healing specialists, in that it affirms Maidu identity, maintains Maidu cultural practices and community, and uses Maidu concepts in the formation of institutions. ${ }^{48}$

While different Maidu conceptualize healing differently, themes of re-acquisition-of places, self, history, and memory - travel through these ideas. My first formal encounter with community "healing" work for holistic recovery and re-building, was with Don Ryberg, Chairman of the petitioning Tsi-Akim Maidu (Taylorsville Rancheria). ${ }^{49}$ Chairman Ryberg was part of a healing group that gathered in the Nevada City area to dialogue on and develop responses to intergenerational trauma. ${ }^{50}$ Ryberg discussed both the need for healing among all people whose ancestors (Native and non-Native, on both sides) were

\footnotetext{
${ }^{40}$ Duran, E. Healing the Soul Wound: Counseling with American Indians and Other Native Peoples. Teachers College Press: New York. 2006: 16.

${ }^{41}$ M.Y.H. Brave Heart and L. DeBruyn 1998.

42 "Takini" means "survivor" or "to come back to life" in Lakota, according to the transcript of a keynote address given by Brave Heart at the Fifth Annual White Bison Wellbriety Conference in Denver, Colorado on April 22, 2005. The transcript is available at http://www.whitebison.org/magazine/2005/volume6/no6.htm. Web site accessed December 10, 2008.

${ }^{43}$ M.Y.H. Brave Heart 2005; and M.Y.H. Brave Heart and L. DeBruyn 1998.

${ }^{44}$ Middleton, E. R. We Were Here, We Are Here, We Will Always Be Here. A Political Ecology of Healing in Mountain Maidu Country. Ph.D dissertation, University of California, Berkeley, 2008.

45 As Cunningham describes in the application for Pacific Watershed and Lands Stewardship Council lands, "Maidu Traditional Ecology is derived from a direct connection to these lands." F. Cunningham 2007: 12.

${ }^{46}$ Gramsci, A. Prison Notebooks, v.1. Columbia University Press: New York. 1975.

${ }^{47}$ E. Duran 2006. M.Y.H. Brave Heart and L. DeBruyn 1998.

${ }^{48}$ Such as Tuhiwai Smith, L. Decolonizing Methodologies. Zed Books: London. 1999; Cornell, S., and J.P. Kalt. "Where Does Economic Development Really Come From? Constitutional Rule among the Contemporary Sioux and Apache." Economic Inquiry 33(3): 402-426. 1995. Brave Heart, M.Y.H. "Clinical interventions with American Indians," in R. Fong and S. Furuto, (eds.) Cultural competent social work practice: Practice skills, interventions, and evaluation. Longman Publishers: Massachusetts. 2001; M.Y.H. Brave Heart and L. DeBruyn 1998; E. Duran1990, 2006. Perhaps composed of linked autonomous parts like the early village-based societies described by Riddell, F., "Maidu and Concow," in R. F. Heizer., (ed.) Handbook of North American Indians, Vol. 8, California. Smithsonian Institution: Washington, D.C. 1978.

${ }^{49}$ Interview, January 13, 2007, Nevada City, California.

${ }^{50}$ Further research is needed on the formation and dynamics of the Truth and Healing Circle, which, at one point, included presentations from Eduardo Duran.
} 
involved in the genocide of California Indians; and the important role for Native people to begin the healing of the land following the destruction of the Gold Rush. Regarding the need to clean up mercury from California waters, Ryberg argued for the central role of Native Californians:

It's the responsibility of the original people to protect their Mother Earth. It's the responsibility of the original people to heal her; it's the responsibility of the original people to their ancestors to take the lead in directing and executing the plan; it is unacceptable for tribes to tag along while someone else does the job of healing. ${ }^{51}$

This statement ties together the importance of the coloniality of power's geopolitical loci of enunciationthat is, identifying who is articulating healing and what side of the colonial difference they are on, which will be discussed below; and underscores the need for attention to articulations and practices of healing at the intersections of political-economy and ecology (i.e., political ecology).

My community partner in the Community and Environmental Research Partnerships Program,Trina Cunningham, is also directly responsible for the importance of the idea of "healing" in this work, as it grows out of her conceptualization of Maidu concerns and hopes for the community. ${ }^{52}$ In 2006, during one of our ongoing discussions about Maidu community development, cultural survival, and resource access, she explained that, "Developing, defining, and enacting a vision for ourselves and our community requires generations of healing." 53 Maidu authors Janice Gould and Michelle LeBeau have also written about the intertwined nature of individual, collective, and ecological healing. ${ }^{54}$ In "A Healing Process," for example, LeBeau describes her personal navigation between Indian and non-Indian worlds, and the roots that came to define her sense of self as she became an adult. She writes:

...my ancestors survived near annihilation through warfare, disease, and assimilation. Northern California Indians were shot on sight for sport and for financial rewards by gold-hungry intruders. My Southern California relatives were massacred at the hands of the Spanish. It is truly a miracle that I ever made it to this world.

Today many things are the same as they were for my ancestors. My grandfather must look at his children and grandchildren and be reminded of the death and heartbreak that he has experienced in his lifetime. I just want my family to be whole and secure. I want my grandfather to be happy. With him in mind, I have done what I do best-learn, not just from books, but from listening and praying. ${ }^{55}$

LeBeau goes on to describe learning her grandfather's Native language (Cahuilla) and spending time in her grandmother's (Pit River, Maidu) country in northern California, getting to know the place and her family there. As such, healing is a return home; a connection with relatives and ancestors in place.

Healing cannot be separated from intergenerational trauma, or the reaction to traumatic experiences that is passed down through generations. In a situation of intergenerational trauma, historical grief ${ }^{56}$ remains unresolved, and children experience similar trauma responses as their parents, even though they did not directly experience the trauma their parents did. ${ }^{57}$ Kiowa author N. Scott Momaday and African American choreographer Alvin Ailey, respectively, refer to a concept of memories that are part of one's very biological reality-embedded in the blood-yet, through this recognition one's identity is strengthened. For example, in Momaday's House Made of Dawn, "the memory in my blood" refers to intrinsic ways of knowing and relating to the world that are so deep they are part of the fabric of one's being. 58 For Ailey, "blood memories" are the deep, cultural aspects that are transmitted through generations and live in the body: "Ailey saw dance as a way to retain the collective blood memories of the

\footnotetext{
51 Middleton, E.R. "Mercury in Our Water, Our Fish, and Our People: Raising Awareness." News from Native California. 21(2): Winter 2007-2008.

52 The CFERPP funds graduate and undergraduate participatory research that is developed in partnership with community groups. See program website at http://www.cnr.berkeley.edu/community forestry/. Site accessed May 15, 2008.

${ }^{53}$ Cunningham, T. Personal communication. August 2006.

${ }^{54}$ Gould, J. Beneath My Heart. Firebrand Books: New York. 1990; and "American Indian Women's Poetry: Strategies of Rage and Hope." Signs 20(4): 797-817. 1995; LeBeau, M. "A Healing Process," Prized Writing 1992-1993, An Anthology from the University of California (1993), reprinted in Frontiers: A Journal of Women's Studies, University of Washington Press, 23:2. 2002.

${ }^{55}$ M. LeBeau 2002: 7-8.

${ }^{56}$ Termed "soul wound" in E. Duran 2006.

${ }^{57}$ M.Y.H. Brave Heart and L. DeBruyn 1998; and Duhl, L. J. Personal communication: Berkeley, California. Fall 2002

${ }^{58}$ Momaday, N. S. House Made of Dawn. Harper and Row: New York. 1968. For analyses of the "memory in the blood" concept, see Siemerling, W. The New North American Studies: Culture, Writing, and the Politics of Re/Cognition. Routledge: New York: 104. 2005; and Allen, C. Blood Narrative. Duke University Press: Durham, North Carolina. 2002.
} 
African-American community." 59 Evoking these "blood memories" in dance was a celebration of an identity that was not taken by colonialism and slavery, and, in that way, a healing from that experience in acknowledgement of both the trauma and survival.

Understanding intergenerational trauma and building "healing" responses are key strategies to undoing the negative manifestations of intergenerational trauma, including violence, addictions, and alienation from natural resources, which are present today in many historically colonized/ traumatized communities. However, despite the general increase in the use of the term "healing" in Native non-profit and governance circles, ${ }^{60}$ Native activism has not necessarily become more responsive to the underlying causes of internal community divisions that manifest, for example, in governance and leadership. Indigenous and coloniality of power scholars are careful to distinguish between the conscious, multi-stage work of de-colonization, and the simple reproduction of colonial realities that has often occurred with independence movements. ${ }^{61}$ While independence/recognition is part of de-colonizing, it may reproduce intergenerational trauma if the colonial structures that sustain the trauma (i.e., devaluation of Native knowledge, exclusion from land management, etc.) are still in place.

\section{Decolonization and healing}

Maidu community members, Lakota intergenerational trauma and healing scholar Brave Heart, and Native American Public Health scholars Dr. Larry Murrillo (Shoshone) and Dr. Leonard Duhl used the term and idea of "healing" to refer to activities that address historical trauma from the basis of a distinctive cosmology, or way of seeing the world. ${ }^{62}$ In contrast, I became familiar with the idea of "decolonization," through studying the coloniality of power and Native Studies literature. ${ }^{63}$ Native Hawaiian scholar Poka Leanui, for example, offers several stages of decolonization: rediscovery and recovery (the learning, relearning, and re-invigorating of Native histories and traditions); mourning (remembering, often accompanied by a great sadness for the cultural knowledge, lands, lifeways, and entire families that have been taken by colonization); dreaming (integrating the rediscovery/recovery of traditional history and knowledge with mourning in order to create contemporary institutions that reflect culture, history, and aspirations as distinct cultures, and as survivors of colonialism); commitment (people make a united decision to pursue a goal); and action (which is not reactive, but built from the previous stages). According to Leanui, these stages can be undertaken in different orders, and for various lengths of time.

Leanui's stages are compatible with Brave Heart's healing model, which includes ceremony, acknowledgement, reclaiming, and community, and Maori scholar Linda Tuhiwai Smith's recognition of the importance of "re-membering," or confronting and then finding ways to address one's painful past and re-claiming one's identity and history in land and community. ${ }^{65}$ Tuhiwai Smith's text represents an interesting intersection of "decolonizing" and "healing," as she recommends ways for researchers to do de-

\footnotetext{
59 Judith Jamison, Ailey's successor as director of the Alvin Ailey Dance Company, in Bates, K. G. "Alvin Ailey's Dance Troupe at 45." National Public Radio: May 27, 2004.

Available at http://www.npr.org/templates/story/story.php?storyId=1912037. Web site accessed April 9, 2008.

${ }^{60}$ As evidenced by conference topics on healing (for example, at Ethnobiology 2007); the creation of community groups such as the "healing" group with Native and non-Native participants in Nevada City, California; presentations (Don Ryberg with Tsi-Akim Maidu, Nevada City, January 31, 2007); literature (for example, from the Takini Network and Eduardo Duran); conferences (Stewarding Sacred Landscapes, organized by the Native American Lands Conservancy in 2006); funding priorities of organizations including Seventh Generation, California Wellness Foundation, and the California Endowment; and the success of organizations that have benefited from these funding priorities, including the Oakland Native American Health Center, and the Arcata Potowat Health Village.

${ }^{61}$ See R. Grosfoguel 2007; and Poka Leanui (Hayden F. Burgess). "Processes of Decolonization," 150-160 in M. Battiste, (ed.) Reclaiming Indigenous Voice and Vision. University of British Columbia Press: Vancouver, British Columbia. 2000. The corollary in Indian country would be attaining federal recognition.

${ }^{62}$ M.Y.H. Brave Heart and L. DeBruyn 1998. Larry Murrillo is an Assistant Professor of Psychiatry at the One Sky Center, a National Resource Center for Native American/Alaska Native Substance Abuse and Mental Health Services located in Portland, Oregon. Len Duhl is a Professor Emeritus in Community Health and Urban Development at the UC Berkeley School of Public Health. The two of them offered a course through the UC Berkeley School of Public Health, entitled "Native American Public Health Issues." I took the course in both 2002 and 2003. I follow definitions of cosmology from Grosfoguel, as the way in which people conceptualize their relationship to other beings and structure their lives accordingly (Grosfoguel, R. Personal communication: San Francisco, CA. February, 2008); and Cajete, "Cosmology is the contextual foundation for philosophy, a grand guiding story, by nature speculative, in that it tries to explain the universe, its origin, characteristics, and essential nature. A cosmology gives rise to philosophy, values, and action, which in turn form the foundation of a society's guiding institutions" (Cajete, G. Native Science: Natural Laws of Interdependence. Clear Light Books: Santa Fe, New Mexico. 1999: 58).

${ }^{63}$ From a limited sample, it appears to me that "healing" is used more often in the public sphere than "decolonization." While it may be true that de-colonization and de-colonize are terms that are used commonly in other communities, I did not hear these terms used among people that I spoke with in the Maidu community. I did hear people speak of healing.

${ }^{64}$ Poka Leanui (Hayden F. Burgess) 2000.

${ }^{65}$ M.Y.H. Brave Heart and L. DeBruyn 1998. L. Tuhiwai Smith 1999.
} 
colonial work with indigenous peoples, in part by recognizing their own positionalities; as well as ways the community can de-colonize itself, including re-naming and re-claiming places. ${ }^{66}$ The latter activities can also be seen as ways to "heal," by addressing the ongoing effects of colonialism and asserting indigenous survival.

The distinction and compatibility, respectively, that I see between healing and de-colonization, particularly in Tuhiwai-Smith's text, help me to separate these two concepts. De-colonization focuses specifically on countering the devaluation of indigenous identity, knowledge, and lifeways that came with colonialism. Decolonization can be framed as both external-researchers need to de-colonize their methodologies, Federal agencies need to de-colonize their ways of consulting with indigenous people, the Federal government needs to de-colonize its system of recognizing tribes-and internal-individuals must de-colonize their way of seeing themselves as colonized people. In contrast, I generally see the term "healing" used to refer to emotional and spiritual processes, which include conscious and holistic recovery, recognition, and re-building within Native individuals, families, communities, and nations. ${ }^{67}$ Healing includes personal efforts to acknowledge the effects of historical trauma in multiple aspects of one's liferelationships, health, etc. - and then conscious work to change any negative patterns in which one might be passing on the trauma. ${ }^{68}$ De-colonization, on the other hand, involves a larger socio-political project of examining and working to dismantle coloniality in multiple arenas, including epistemic, social, political, and economic. Healing may seem impossible without some decolonization.

In 2005, for example, I was discussing dissertation ideas with Farrell Cunningham (Maidu), when he asked, "How can we talk about healing when the onslaught against our language and culture is still going on, within our own communities?"69 He proceeded to refer to several elements of coloniality and intergenerational trauma, including lack of Federal recognition, lack of unified leadership, and lack of both institutionalized support and local desire to maintain and build Maidu cultural identity and knowledge. Franz Fanon's work on treating colonized patients within a colonial context that continually creates the conditions of illness is relevant to this situation, in which Maidu are constantly confronted by policies that disallow cultural practices, and maintain fractured or nonexistent access to land. ${ }^{70}$ The larger society perpetuates grief by not acknowledging what happened, and by continuing to create the conditions for ongoing trauma. The Stewardship Council Board, for example, has not yet formally acknowledged that the lands they are charged with divesting in the Feather River watershed are Maidu lands, violently taken from Maidu just 100-150 years ago. Such a formal acknowledgement would, ideally, precipitate a Council process in which return of those lands to Maidu (and to other tribes in other areas), would achieve a "Beneficial Public Value" of social justice. ${ }^{71}$ Without this recognition and steps to make change, Maidu daily live a legacy of "settler colonialism," or continuing to live in a colonized homeland. This distinguishes Indian communities from many other American communities of color who have fled the sites of their oppression. Healing efforts are challenged by the fact that colonial structures remain in place. As such, decolonization facilitates the ability to heal.

The interplay between decolonization and healing is also apparent in coloniality theory, for example, in Nelson Maldonado-Torres' description of the process of "de-colonizing being." Given that indigenous peoples' humanity was disregarded during and following the colonizing process, attempting to "de-colonize

\footnotetext{
${ }^{66}$ For a discussion of indigenous re-naming of places, see LaDuke, W. Recovering the Sacred. South End Press: Cambridge, Massachusetts. 2005.

${ }^{67}$ For example, Ramirez, R. "Healing Through Grief: Urban Indians Reimagining Culture and Community in San Jose, California." American Indian Culture and Research Journal 22(4): 308. 1998; Silver, S. M., and J. P. Wilson. "Native American Healing and Purification Rituals for War Stress (337-355), in Wilson, J. P., Z. Harel, and B. Kahana, (eds.) Human Adaptation to Extreme Stress: From the Holocaust to Vietnam. Plenum Press: New York. 1988; Nebelkopf, E. and M. Phillips, (eds.), Healing and Mental Health for Native Americans: Speaking in Red. AltaMira Press: Walnut Creek. 2004; M.Y.H. Brave Heart and L. DeBruyn 1998; M. LeBeau 2002; E. Duran 1990; E. Duran and B. Duran 1995; E. Duran 2006.

${ }^{68}$ Ward Churchill offers a discussion of intergenerational trauma, as demonstrated by the abusive behavior of residential school survivors toward their children (Churchill, W. Kill the Indian, Save the Man: The Genocidal Impact of American Indian Residential Schools. City Lights Books: San Francisco, CA. 2004: 68-73). Brave Heart and DeBruyn discuss similar patterns among survivors and offer suggestions for psychological intervention and support (M.Y.H. Brave Heart and L. DeBruyn 1998: 63-64, 73).

${ }^{69}$ Cunningham, F. Personal communication. 2005.

${ }^{70}$ Fanon, F. The Wretched of the Earth. Grove Press: New York. 1963.

${ }^{71}$ The Council is charged with ensuring that each divested parcel is conserved for a range of six Beneficial Public Values (see footnote 3 for a list of these). Social and/or environmental justice is not one of the listed values. At the April 30, 2009 Stewardship Council Board Meeting in Redding, California, Maidu Summit Secretary-Treasurer Lorena Gorbet asked the Council to adopt a formal consideration of "social justice," in terms of returning lands taken from Native Californians, in their land divestiture plans. The Council Board President, Mike Chrisman, directed the Council's Executive Director, Allene Zanger, to discuss this further with Council board member Larry Myers, Executive Director of the Native American Heritage Commission, and Gorbet. As of May 15, 2009, Gorbet had not been contacted by the Council to follow up on this directive.
} 
being" is a healing endeavor because it is a personal and community effort to re-build one's humanity and cosmology. ${ }^{72}$ The ways in which healing was discussed in the Maidu community included aspects of decolonization - in terms of asserting rights to land and protecting sites from developers and Federal resource management agencies; and healing-or building empowering ways to respond to coloniality and recover health (understood holistically) among and between all segments of the population.

I interpret "healing" as a spiritual and emotional process by which individuals, families, and the community itself address historical trauma-for example, related to Indian boarding schools which separated families and involved cultural suppression, humiliation, and, often, abuse; land seizures; and dispersion of people for work and also for boarding school. ${ }^{73}$ Participants in the process of healing look at how these historical events and their consequences (lack of land, lack of structures for conflict resolution, lack of recognition, etc.) are affecting people's lives in the present. The work then is to develop actions and interventions to recognize and address the intergenerational grief. The range of Maidu activism I focus on is explicitly de-colonial and/or healing, or neither-and it actually reinforces coloniality. Through the example of activism, however, the concepts of healing and de-colonization may be explored, with insights from political ecology. Activism often involves the stages of healing or de-colonization noted above, including ceremony, reclaiming, re-naming, recovery, and the formation of coalitions and other types of governance. According to the work of Brave Heart and DeBruyn, and trauma and loss scholars David Eng and David Kazanjian, unrecognized grief as it relates to intergenerational trauma plays a strong role in whether people are able to develop new, de-colonial systems that change the pattern created by the oppressor. 74

\section{Governance and healing}

Governance was a key element that came up in community discussions of the term "healing." The recognition of some Maidu, based upon their residence on the rancheria at the time of termination, is a source of frustration, particularly for unrecognized community members. "Divide and conquer-it's what the government is best at with Indian people," according to MCDG Coordinator Lorena Gorbet. "And then we carry it on ourselves," added Trina Cunningham. ${ }^{75}$

Political ecology has been attentive to governance, particularly in terms of the role of the State in defining territory to establish authority, and the ways in which marginalized groups have actively resisted the State's criminalization of their resource practices. ${ }^{76}$ Environmental anthropologists, whose work informs and is informed by political ecology, have also examined the intersection between State and paraState enforcement of environmental narratives, and the variation in local responses, as based on the range of indigenous relationships to resources in a given community. ${ }^{77}$ However, despite Peet and Watts' call to focus further attention on social movements and confrontations between environmental imaginaries, respectively, little attention has been granted to the contemporary and internally contested processes of developing environmental governance in marginalized indigenous communities within first world nations. ${ }^{78}$ I draw on the following theorists to examine successful Native governance strategies, and how they relate to the indicators of healing and de-colonizing noted in the previous section.

Founders of the Harvard Project on American Indian Economic Development, Joseph Kalt and Stephen Cornell encourage tribes to develop governance models that are culturally congruent, or built on shared tribal cultural values that translate into a system of laws and government. ${ }^{79}$ For a formerly colonized

\footnotetext{
${ }^{72}$ N. Maldonado-Torres 2007.

${ }^{73}$ On abuse, see Adams, D. W. Education for Extinction. University Press of Kansas: Lawrence, KS. 1995; and W. Churchill 2004. Some Maidu were sent as far away as Carlisle school in Pennsylvania, and some of their descendents remain there today. See, for example, the allotment files on Eli Peazzoni Bill (Sus-424) and Emma Bill (Sus-426), in Case Files of Land Transactions, 1909-1956; Susanville; Records of the Bureau of Indian Affairs; Record Group 75; National Archives, Pacific Region (San Francisco), San Bruno, California.

${ }^{74}$ M.Y. H. Brave Heart and L. DeBruyn 1998. Eng, D., and D. Kazanjian, (eds.) Loss: The Politics of Mourning. University of California Press: Berkeley, CA. 2003.

${ }^{75}$ Gorbet, L., and T. Cunningham. Personal communication: Greenville, California. 2006.

${ }^{76}$ See, for example, Vandergeest, P., and N.L. Peluso. "Territorialization and State Power in Thailand." Theory and Society 24(3): 385-426. 1995; Winichakul, T. Siam Mapped. University of Hawaii Press: Honolulu. 1997; Craib, R. Cartographic Mexico. Duke University Press: Durham, North Carolina. 2004.

${ }^{77}$ See, for example, Snodgrass et al. "Witch Hunts, Herbal Healing, and Discourses of Indigenous Ecodevelopment in North India." American Anthropologist 110(3): 299-312. 2008; Brosius, Peter. "Green Dots, Pink Hearts: Displacing Politics from the Malaysian Rain Forest." American Anthropologist 101(1): 36-57. 1999.

78 Peet, R., and M. Watts. Liberation Ecologies: Environment, Development, and Social Movements. 1996: Introduction.

79 Kalt is Ford Foundation Professor of International Political Economy, and Co-Director, Harvard Project on American Indian Economic Development, John F. Kennedy School of Government, Harvard University. Among other roles Cornell is Director, Udall Center for Studies in Public Policy at the University of Arizona, and Co-Director of the Harvard Project. See Cornell, S., and J.P. Kalt, (eds.) What Can Tribes Do? Strategies and Institutions in American
} 
nation that has won independence and the right to govern itself, effective and inclusive internal governance cannot just repeat the pattern of the colonizer. ${ }^{80}$ Native American legal scholar Robert Williams (Lumbee), Director of the Indigenous Peoples Law and Policy Program at the University of Arizona, offers a series of indicators of effective tribal governments, including: stability (long terms for Council members); cultural congruency (the government structure matches cultural norms); independent dispute resolution (separate from the tribal government); staggered terms (for institutional memory); reliable bureaucracy (to manage accounts, oversee personnel, and interact with other parties); and a separation of powers. ${ }^{81}$ To meet these guidelines, Native governance must undergo decolonization and "healing"—including individual and group understanding of the events that occurred in the colonial era and their continuity with the present; an examination of people's internalization of colonialism, and a detailed look at how they enact this individually and in governance; and steps to create a de-colonized government built on specific tribal values. I see the Summit and its member groups as working through aspects of this process.

Ramon Grosfoguel has argued that the task of the liberated nation is to understand global systems of domination, as manifested in intertwined hierarchies like male/female, white/non-white, Christian/nonChristian, and respond with a system that rejects this heterarchy; is built on cultural identity and values (as these are understood within the nation); and is ultimately empowering for its people. ${ }^{82}$ As such, "border thinkers" who acknowledge their colonial history, see themselves as survivors, and work to create an alternative modernity on their own cultural foundations, can build a liberated nation. ${ }^{83}$ Drawing on Argentinian philosopher Enrique Dussel, a border thinker is aware of multiple epistemologies, including the dominant epistemology founded upon colonial difference, and chooses to identify and foreground an indigenous epistemology in a contemporary context. While indigenous social structures involved hierarchies, they were different hierarchies than the globalized institutionalization of white/non-white, and literate/oral, for example. ${ }^{84}$ Healing, then, requires a review of what remains of the indigenous traditions of governance, and a selection of what works for the community in the present. According to Farrell Cunningham, a contemporary Maidu world could be built upon the Maidu tenet of generosity, in which the leaders are the people who give the most, and even what appears as selfish is guided by the intention of generosity. ${ }^{85}$ As Worldmaker told the people when He created them, yahat yamaitodom, or "you will be good to each other." As Cunningham and I discussed, it becomes challenging to operationalize this ideal in a context of internal and external incentives to reproduce the American system of governance and/or to exclude others based on desire for power and lack of trust.

Governance in Native communities cannot be separated from intergenerational trauma and efforts to heal. In Maidu country, some of the most innovative efforts (such as the Maidu Summit) to create new modes of leadership and action in the community also strive to create new modes of governance. The Summit confronts internal and external factors that cause division. Efforts to reform governance remain one of the key threads in this research on Maidu efforts to "heal" or re-build from a legacy of external and internal coloniality and its resulting intergenerational trauma.

\section{Activism}

Central to the new political ecology is a sensitivity to environmental politics as a process of cultural mobilsation. ${ }^{86}$

I began my work in Maidu country with the idea that "activism," like that exemplified in the formation of the Maidu Summit, fulfills the Freireian definition of turning anger at oppression outward to make

\footnotetext{
Indian Economic Development. University of California, Los Angeles: American Indian Studies Center (1992); "Sovereignty and Nation-Building: The Development Challenge in Indian Country Today." American Indian Culture and Research Journal 22(3): 187-214. 1998; S. Cornell and J.P. Kalt 1995.

${ }^{80}$ By "effective" I mean governance that provides important services (social services, protection, infrastructure), and that has a functional structure by which decisions are made and acted upon. By "inclusive," I mean governance that incorporates representatives of the different groups (ethnicities, political parties, ages, classes) in a nation. Williams' recommendations are similar to those in S. Cornell and J.P. Kalt 1992, 1995, 1998. See R. Grosfoguel 2007.

${ }^{81}$ Williams, R. A. "Why are Some Native Nations More Successful than Others?" Lecture: September $26,2006$. University of California, Berkeley.

${ }^{82}$ As used by Grosfoguel, the term "heterarchy" describes the multiple and intertwined hierarchies that structure the contemporary world. R. Grosfoguel 2007; W. Mignolo 2007; N. Maldonado Torres 2007.

${ }^{83}$ This is an example of Enrique Dussel's concept of alterity, or alternative modernity, as elaborated upon in Dussel, E. Philosophy of Liberation. Orbis Books: New York. 1980.

${ }^{84}$ E. Dussel 1980; Mignolo, W. Local Histories, Global Designs. Princeton University Press: Princeton, New Jersey. 2000; Moraga, S., and G. Anzaldúa, (eds.) This Bridge Called My Back: Writings by Radical Women of Color. Kitchen Table: Women of Color Press. February, 1984. See also Dixon, R. B. The Northern Maidu. American Museum of Natural History Bulletin 17(3). Knicker-bocker Press: New York. 1905; F. Riddell in Heizer, (ed.), 1978.

${ }^{85}$ Cunningham, F. Personal communication. March 2007.

${ }^{86}$ Michael Watts 2000.
} 
change, rather than letting it fester inside or turning it on one's self and community. ${ }^{87}$ Seen in this light, activism is also a manifestation of healing from intergenerational trauma. This healing is at least partially achieved by actively de-colonizing the institutions and internalized subjectivities that perpetuate trauma. Given the relationship of the Maidu homeland to Maidu identity, I focus on Maidu natural resources activism. Activism regarding natural resources can be better described using a synthetic approach that combines perspectives from political ecology with ideas of coloniality and healing/trauma/de-colonizing. This combination of frameworks can approach the complexity of this activism as simultaneously decolonial/ healing, and intertwined with intergenerational trauma.

On one hand, activism can be seen as a manifestation of healing, as activists are people who have healed to the point where they can envision themselves as effective and engage in activism. Activism can also be seen as contributing to healing, as the activist moves from feelings of defeat to a sense of empowerment to create change. However, in two years of participatory fieldwork in Mountain Maidu country, it became clear to me that "activism," even as it may constitute an external expression of frustration, can be divisive as often as it can be healing. Activism's applicability to healing is often linked to scale; for example, while activism may be productive for an individual's sense of empowerment, it may be counter-productive to community-wide efforts. The patterns of formation and dissolution of Maidu groups and efforts often included the emergence of at least one leader who, at some point, started to exclude others, driving the group apart. As such, the individual leader may have reached a "healing" to some degree, in terms of his/her ability to work for change, but opportunities for "healing" in the group were diminished.

Activism is additionally complex partially because the sense of empowerment that leads people to agitate to protect specific rights and resources can result just as much from internalizing intergenerational trauma - for example, by accepting colonially imposed divisions between people — as it can from having undergone a "healing" process by addressing the impacts of intergenerational trauma. Activism cannot be isolated from conflicts within the Maidu community. On one level, these conflicts are just conflicts between people, as in any community, exacerbated by the fact that there is no larger cultural or social structure for conflict resolution. ${ }^{88}$ On another, these conflicts are rooted in the intergenerational trauma initiated by a century and a half of destructive, assimilationist policies. ${ }^{89}$ The traumatic experiences associated with colonialism, which continue to affect Maidu at individual, family, community, and national levels, include the forced reorganization of the Maidu political-cultural-economic community; the taking of Maidu resources and homes, leaving people homeless and competing for limited resources; the out-and-out destruction of Maidu communities; and the devaluation and attempted destruction of a Maidu cosmology. ${ }^{90}$

Contemporary and historic Maidu activism occurs within and struggles against a neo-colonial context in which regulations and political-economic structures attempt to actively deny people the opportunities to continue to practice their culture. One recent example is the 2007 Forest Service regulations, which required unrecognized Native people to get a permit to tend and collect plants on Forest Service land. ${ }^{91}$ Maidu depend on resources located on these lands, such as beargrass for weaving and other plants for medicines. $^{92}$ Under the proposed regulations, in order to buy gathering permits, unrecognized Native people would have to identify and share the location of areas where they gathered. Because of historical

${ }^{87}$ In reference to the Brazilian scholar Paolo Freire, as described in Freire, P. Pedagogy of the Oppressed. Continuum: 1970.

${ }^{88}$ For example, in the midst of a 2006 conflict about some of Farrell's statements in a film made of Maidu community members, one elder remarked that people would traditionally smoke and pray together after a difficult discussion, in order to show that, even though there were differences of opinion, there was still a sense of unity as a community and as a people. However, there was no forum in which this could take place. In reference to the same event, Farrell Cunningham suggested that the conflict be solved in a traditional Maidu manner, with a handgame, but those opposed to his point of view on the film were unwilling to engage in a handgame with him. (Notes from meeting and preceding conversations, April 6, 2006, Greenville, California, on file with author). Cornell and Kalt also discuss the importance of an agreed-upon system of conflict resolution as one element of successful Native governance. (S. Cornell and J.P. Kalt 1992). For a description of the complexity of conflict resolution, even when there is an agreed-upon system for resolution, that is nested within state structures for resolution, see Gezon, Lisa. "Political Ecology and Conflict in Ankarana, Madagascar." Ethnology 36(2): 85-100. Spring 1997.

${ }^{89}$ For an example of how the contemporary configuration of resources is built upon historical policies, see is Romm, $\mathrm{J}$. "The Coincidental Order of Environmental Justice," in K. Mutz, G. Bryner, and D. Benner, (eds.) Justice and Natural Resources: Concepts, Strategies, and Applications. Island Press: Washington D.C. 2002.

90 Cosmology is defined here as the understanding of self and relationship to other beings that underlies knowledge, language, and traditional ecological stewardship.

${ }^{91}$ The Forest Service issued a proposed final Special Forest Products Rule on October 22, 2007, governing the removal of special forest products and botanical products from National Forest System lands (FR Vo. 72, No 203, Doc E 7200658). On May 27, 2009, the Forest Service announced that the rule was delayed indefinitely, because of the large number of comments received and the need to address all of the concerns therein.

${ }^{92}$ Plumas County is $75 \%$ National Forest land, so barring people from gathering on National Forest land effectively bars them from gathering on the vast majority of County land. 
site exploitation, and cultural rules about what type of information on the location of family resources is imparted to non-relatives, Maidu are reluctant to share exactly which areas they use. ${ }^{93}$ In contrast, tribes with treaties with the U.S. Government can establish formal protocols and receive permits for gathering. Because of the history of California Indian policy, there are no treaties with tribes in California, and a large number of California Indian people are unrecognized. ${ }^{94}$ As such, unrecognized people are further penalized under these particular gathering regulations for the Federal government's arbitrary lack of recognition of them. As a greater irony, many of these unrecognized tribes are seeking Federal recognition, a process that requires them to provide proof of "cultural continuity" over time. This latest gathering regulation is part of a series of regulations and laws since European contact that have attempted to force Maidu people to stop practicing their cultures, while they are simultaneously being asked to prove to the Bureau of Acknowledgement and Research that they are still practicing Maidu culture.

I relate this neo-colonial policy to underscore the reality of what activism - to build community, maintain cultural knowledge and practices, and sustain access to resources and to policymaking-must confront. The importance of ceremony in activism becomes clear in this context, because, as one Maidu/ Wailaki elder told me:

[Thinking of these things] makes you angry. But you learn how to deal with it. People can't carry all of that anger and pain around inside of them or they can't care for themselves or for their families and communities. We've been working on healing for a long time. ${ }^{95}$

As such, healing is always a kind of activism - a directing of energy to make change, which enhances individual and community survival-but activism is not always healing, at least on the community level. Efforts to make change, inside and outside of the community, do not always represent a reversal of intergenerational trauma-in fact, they may represent a manifestation of it as people try to exclude or silence one another.

Brave Heart and DeBruyn indicate that activism must have a foundation in some level of ceremony, whether that is a "traditional" ceremony that has been practiced in the community for thousands of years, in which some element of a distinctly Maidu cosmology is recognized and re-asserted; or a contemporary ceremony initiated to re-affirm a relationship with a resource and between people. Engaging in ceremony connotes a shared investment and belief in something larger than the activity itself. However, if that intention for creating unity is not there in the community before the ceremony takes place, and there are divergent efforts, lack of communication, and lack of trust between individuals and families, the very ceremonies may include controversies themselves.

Contemporary Maidu activism is directed externally: to change policies, maintain an Indian voice at the table in resource management and other decisions, and through ceremonies that affect the entire world. ${ }^{96}$ It is also directed internally at the community itself through education, cultural activities, attempts to develop a unified governing structure, and ceremony. When people transcended internal conflicts to come together and put forth a unified cultural and community voice, it helped to bring resources and attention to the Maidu community from the outside, lending support to efforts to get resources back for Maidu individuals and organizations. As Trina Cunningham and I discussed, perhaps the community needed more space and time for internal community building, before taking on external efforts. ${ }^{97}$ However, both internal and external activism had to happen simultaneously because of the threats to irreplaceable

\footnotetext{
${ }^{93}$ Sites that Maidu specifically ask be protected were disturbed and partially destroyed. For a comprehensive discussion of what happened to the beargrass site near Canyon Dam, see London, J. Placing Conflict and Collaboration in Community Forestry. PhD Dissertation: University of California, Berkeley. 2001. Following a description of the desecration of the site, London writes, "..many other Maidu viewed the destruction as a clear signal that protecting gathering sites would be better achieved through maintaining silence about their practices than through collaborating with the Forest Service" (J. London 2001: 56-57). As he quotes a woman he calls Jerry-Ann, "Its made a lot of people want to keep going on the ground, you know, much as my great grandparents did. They just kept it all hidden. Like the baskets, and kept the language hidden or just didn't teach it all. And that's some of the feelings that it evoked again. It just, don't even work with them. Just keep what ever you can to yourself. And do what you can, while you can, where you can" (J. London 2001: 57). There was frustration within the Maidu community, among individuals who had shared their specific gathering places with other Maidu only to return to those sites and find them over-harvested, as the new user had not followed the same gathering protocol as the original site steward. Interviews C4, C3, and Farrell Cunningham, 2006-2008.

${ }^{94}$ For a list of treaties and agreements with tribes, see Prucha, F.P. American Indian Treaties. UC Press: Berkeley, CA. 1994.

${ }^{95}$ Maidu/ Wailaki elder. Personal communication. April 15, 2008.

96 As exemplified by united Maidu activism to have a voice in the PG\&E Stewardship Council Proceedings, particularly at the 2004 Stewardship Council Board of Directors meeting in Mountain Maidu country, held June 29, 2004, in Chester, CA. Ceremonies include the Bear Dance. For more on the Bear Dance, see Dixon 1905; Manlove, Robert. "The Mountain Maidu Bear Dance." News from Native California 22(3). Spring 2009; and Hunt, Leigh Ann. Rite of Spring: A History of the Mountain Maidu Bear Dance. Lassen County Historical Society: 1996.

${ }^{97}$ Cunningham, T. Personal communication. 2006-2008.
} 
Maidu cultural resources and the brief institutional openings (such as the Stewardship Council land divestiture) to gain some restitution for Maidu land takings and cultural disruption. ${ }^{98}$

From the colonial period to the coloniality of the present, Maidu activism has always challenged manifestations of coloniality. The contemporary formation of efforts like the Maidu Summit are the latest in a series of attempts to bring people together across historical divisions (pre-existing colonialism), imposed divisions (by colonialists), and (accepted) internal divisions to maintain Maidu survival, and to maintain the survival of the natural resources that are expressions of Maidu relationship and interrelatedness.

\section{Discussion}

Subaltern political ecology is border work, in the sense that Walter Mignolo talks of borderlands as a fertile meeting ground of ideas and identities. ${ }^{99}$ The ideas in this article emerged from several years of research and partnership with Maidu activists, and parallel, simultaneous engagement with scholars in ethnic studies, public health, and political ecology at the University of California, Berkeley and the University of California, Davis, USA. I make an intellectual intervention to connect these very different epistemic, cultural, geographic, and political locations by offering a theoretical framework that emerged from both Maidu thinkers and myself; from academic perspectives and rural, indigenous perspectives. Throughout the process of writing this article, I consulted with Maidu community members, some of whom provided written and verbal feedback.

\section{Antecedents and pathways}

The political ecology and coloniality of power approaches share a history of Marxist explanation and critique of the constitutive nature of inequality to capitalist production. ${ }^{100}$ As part of the proto-Capitalist process of primitive accumulation, the State, or dominating individuals and/or groups with the support of the State, expropriate the land and other natural resources. ${ }^{101}$ The dispossessed masses then become workers, beholden for their livelihoods to the owners of the means of production. The political ecology approach draws, in part, on this political-economic relationship between people and resources.

Political ecology also has antecedents in anthropological systems theory, and ecological anthropology, in terms of examining human-environmental relations. ${ }^{182}$ Early ecological anthropology saw culture and environment as a self-regulating system, but as ecological theories moved towards recognising disequilibria, anthropologists similarly challenged the notion of bounded cultures in self-regulating environmental relationships. ${ }^{103}$ Environmental anthropologists began looking at human-environmental systems as multi-level, complex, and interconnected. ${ }^{104}$ The meaning of resources and relationships to resources began to be attached to power, as Kottak explains:

\footnotetext{
98 Threats during the time I was there included large and small private developments (an example of a large development being the Dyer Mountain Project Area); dam re-licensing; the PG\&E Stewardship Council Divestiture; and mining on Soda Rock. For more information regarding Maidu concerns with the Dyer Mountain Project proposal, a large development near Mountain Meadows, see North Fork Associates. Dyer Mountain Resort: Recirculated Draft EIR. July 2006; and anthropologist Sarah-Larus Tolley's letter on behalf of the Honey Lake Maidu to stop the development, at http://www.honeylakemaidu.org. Site accessed June 8, 2008.

${ }^{99} \mathrm{~W}$. Mignolo 2007. Walter Mignolo is a professor of literature and romance studies, and cultural anthropology at Duke University, where he also directs the Center for Global Studies and the Humanities.

${ }^{100}$ Marx, K. Capital: A Critique of Political Economy. Volume 1. Translated by Ben Fowkes. Vintage Books: New York. 1977.

${ }^{101}$ A good example of the State's favoritism in the distribution of and control over resources is found in Jeff Romm's description of the way in which lands in the American West were distributed via the Homestead Act to whites, excluding African Americans, Asian Americans, and Native Americans from opportunities to file on certain lands. (J. Romm 2002).

${ }^{102}$ For example, Bateson, G. Steps to an Ecology of Mind: Collected Essays in Anthropology, Psychiatry, Evolution, and Epistemology. University Of Chicago Press. 1972. Rappaport, Roy A. "Ritual Regulation of Environmental Relations Among a New Guinea People," in Andrew Vayda, (ed.), Environment and Cultural Behavior: Ecological Studies in Cultural Anthropology. The Natural History Press: Garden City. 1967.

${ }^{103}$ Kottak, Conrad P. "The New Ecological Anthropology." American Anthropologist 101(1): 23-35. March 1999.

104 See, for example, Gezon 1997: "By focusing on links between local, national, and international contacts, scholars have shown that ecological relationships extend beyond local geographical and political boundaries, and that social differentiation is an important factor in resource management, as some possess greater rights to access and manage resources than others."
} 
...the new ecological, or environmental, anthropology blends theory and analysis with political awareness and policy concerns...[it] attempts not only to understand but also to devise culturally informed and appropriate solutions to such problems and issues as environmental degradation, environmental racism..."105

Environmental anthropologists also consciously worked to retain the specificity of ethnography in order to give due attention "...to the specifics of local culture and social structure." ${ }^{106}$ In the coloniality of power approach, political awareness and power-particularly the imbalance of power initiated by colonial domination and neocolonial research practices-are taken as given, and ethnographic work is always situated within a context of coloniality. ${ }^{107}$

Theorists of political ecology, and the coloniality of power, both draw upon world systems theory and the concept of the development of underdevelopment, which build on Marxist thought to emphasize the global unequal distribution of resources as part of an international political economy of domination and subjugation. ${ }^{108}$ For coloniality of power theorists, however, race (not class) is the axis of this politicaleconomic-sociocultural inequality. W.E.B. DuBois influenced coloniality of power by articulating the connections between natural and financial resource development and racial oppression in America. ${ }^{109}$

According to Grosfoguel, both the dispossession of American Indians and the exploitation of African Americans are rooted in a very particular type of racism: epistemic racism, or the systematic, institutionalized devaluation of knowledge and ways of knowing of the oppressed. ${ }^{110}$ This epistemic racism also seems to manifest in the historical amnesia of dominant institutions, in which only certain memories are valid. In the case of the Stewardship Council, for example, the paradigm of restoring and conserving land to a remembered/imagined past is valid; but the paradigm of returning land, based on a remembered taking, is less valid. As Mignolo explains, epistemic racism forms the key intellectual basis for environmental, social, and economic inequality:

In the New World...racism was an epistemic operation that institutionalized the inferiority of the Indians and, subsequently, justified genocidal violence... and exploitation of labor...Race was, in the colonies and before the industrial revolution, what class became after the industrial revolution in Europe. ${ }^{111}$

By simultaneously institutionalizing the double myth of European racial superiority and the inferiority of indigenous people around the globe, colonizers could claim Native lands and organize systems of exploitative labor that enabled the development and rise of international capitalism on an unprecedented scale.

Given the division of the globe along the lines of this colonial difference, coloniality of power scholars underscore the importance of clarifying the geopolitical loci of enunciation, i.e. "where you are thinking from." 112 For example, dependency theory issued partially from Latin American and African American scholars arguing that the developed countries built their prowess specifically on the backs of oppressed

\footnotetext{
105 Kottak 1999: 25; and see Snodgrass et al. 2008 (p309), "Political ecological theories of environmentality illuminate the ways that the meanings and values attached to nature, including our own analytical assumptions and scholarly traditions, unfold in historically specific contexts of power and inequality".

${ }^{106}$ Kottak 1999: 31.

${ }^{107}$ For a discussion of the importance of recognizing and responding to the neocolonial conditions of possibility of both historic and contemporary anthropology, see Biolsi, Thomas, and Larry Zimmerman. Indians and Anthropologists: Vine Deloria, Jr. and the Critique of Anthropology. University of Arizona Press. 1997; and Deloria's original incisive critique, entitled "Anthropologists and Other Friends," in Custer Died for Your Sins: An Indian Manifesto. University of Oklahoma Press: Norman, OK. 1988. (Originally published 1969).

108 On World Systems Theory see Wallerstein, I. The Capitalist World-Economy. Cambridge University Press: Cambridge, UK. 1979. Wallerstein, I. "The Inventions of TimeSpace Realities: Towards an Understanding of our Historical Systems," in Unthinking Social Science: The Limits of $19^{\text {th }}$ Century Paradigms. Temple University Press: Philadelphia, Pennsylvania. 2001: 135-148. German economic historian and sociologist Andre Gunder Frank is perhaps the most well known proponent of dependency theory. Gunder Frank lived and worked in Europe, the United States, and Latin America. See Gunder Frank, A. "The Development of Underdevelopment" in Latin America: Underdevelopment or Revolution. Monthly Review Press. 1969. Former Brazilian president and sociologist Fernando Henrique Cardoso articulated the operation of dependency theory in Latin America in Cardoso, F. H. and E. Faletto. Dependency and Development in Latin America. Translated by Marjory Mattingly Urquidi. University of California Press: Berkeley, CA. 1979.

${ }^{109}$ DuBois, W.E.B. Black Reconstruction in America: 1860-1880. Harcourt Brace: New York. 1935.

110 R. Grosfoguel 2007.

${ }^{111}$ W. Mignolo 2007: 479.

112 The "colonial difference" is the classification of peoples around the world as either "modern" or "primitive." The colonial difference has had several definitions_-including the presence or absence of an alphanumeric writing system, or one's location in the global South (periphery) or North (core), but it is always, as Mignolo explains, "...a machinery to expand difference into values." (W. Mignolo 2000: 3, 12.)
} 
people. ${ }^{113}$ As such, it came from theorists writing from the very contexts in which oppression was ongoing. While coloniality of power theorists engage in productive dialogue with scholars like Immanuel Wallerstein, it is also part of their critical framework to examine the geopolitical location from which he is writing and thinking.

The loci of enunciation is a response to a history of what Mignolo calls "global designs," or universalizing concepts that are imposed by what Donna Haraway refers to as the "voice from nowhere," thereby hiding their designers' "local histories," or where the author comes from and how s/he developed his/her ideas. ${ }^{14}$ Knowledge specifically produced from the subaltern side of the colonial difference issues from thinkers acknowledging and engaging with their historical and contemporary positionality on the side of the colonial difference where knowledge is invalid. Those speaking from this disenfranchised location offer a "subaltern perspective," that is:

...not from the colonial/Christian discourse of...colonialism, but from the perspective of its consequences, that is, the repression of American Indians, African slavery, and the emergence of a Creole consciousness...in subaltern and dependent positions. ${ }^{115}$

As such, it matters very much both who is speaking, and where s/he locates him/herself in terms of the colonial difference, and how s/he makes that explicit in the methodology, questions, and outcomes of his/her work. This idea is reflected in anthropological reflexivity, although reflexivity has not always been politicized, and the concept of loci of enunciation is inherently both political and reflexive. As such, a consideration of the loci of enunciation would contribute to scholarship in political ecology. ${ }^{116}$

The de-colonial world is one in which the conditions of ideas and the loci of their enunciators is clear:

The Decolonial Turn is about making visible the invisible and about analyzing the mechanisms that produce such invisibility or distorted visibility in light of a large stock of ideas that must necessarily include the critical reflections of the 'invisible' people themselves. ${ }^{117}$

In order to de-colonize, one must understand and articulate the specific ways in which coloniality operates in knowledge, culture, governance, and other spheres of human life. Recognizing "fundamental difference" in worldviews without assigning rank or evolutionary potential is de-colonizing. ${ }^{118}$ I have attempted to do this by including the voices of community members as theoretical perspectives representing a submerged, yet distinct, empistemology.

\section{Engaging political ecology}

Political ecology has brought streams of thought from geography, anthropology, ecology, and other disciplines together to better understand the multi-scalar and cross-temporal complexity of environmental issues, as embedded within socio-cultural factors. ${ }^{119}$ However, political ecology could engage more deeply with the colonial effects upon, and responses by, both academics and community members that have critical analyses to make of how coloniality is experienced. While political ecology has privileged a modified Marxist focus on political economy, and analyses of discourse, contingency and interconnection, I propose a neccessarily politicized emphasis on the ways in which cultural and epistemic factors (including intergenerational trauma, healing, and decolonization) determine human-environment relations. ${ }^{120}$

\footnotetext{
113 See F. H. Cardoso 1979; and W.E.B. DuBois 1935.

114 See Haraway, D. "Situated Knowledges," in Simians, Cyborgs, and Women: The Reinvention of Nature. Routledge: New York. 1991 and W. Mignolo 2000.

115 Mignolo, W. “The Geopolitics of Knowledge and the Colonial Difference.” South Atlantic Quarterly 101(1). 2002: 66.

116 See, for example, Hymes, Dell, (ed.) Reinventing Anthropology. Ann Arbor: University of Michigan Press 1999 (originally published 1972); and Fischer, Michael M. J., and George E. Marcus, (eds.) Anthropology as Cultural Critique. Chicago: University of Chicago Press, 1986. Rabinow, Paul. Reflections of Fieldwork in Morocco. University of California Press: Berkeley, California. 1977.

${ }^{117}$ N. Maldonado-Torres 2007: 262.

${ }^{118}$ Deloria, Jr., V. God is Red: A Native View of Religion. Fulcrum Publishing: Golden, Colorado. 1994: 62.

119 See, for example, Hecht's illumination of the convergence of factors that enabled the rubber planters to gain international attention (Hecht, S. B. "Environment, Development, and Politics: Capital Accumulation and the Livestock Sector in Eastern Amazonia." World Development. 13:6. 1985; and Rick Schroeder's work on the unforeseen effects of development interventions on local gender dynamics in Gambia. (Schroeder, R. A. 1997. "Re-claiming" land in the Gambia: Gendered property rights and environmental intervention." Annals of the Association of American Geographers 87 (3):487-508)

${ }^{120}$ See, for example, Hajer, M., The Politics of Environmental Discourse. Clarendon Press: Oxford/ New York. 1995; and Raffles, H. In Amazonia: A Natural History. Princeton University Press: Princeton, New Jersey. 2002. The latter approach is exemplified by Tsing, A. Friction: An Ethnography of Global Connection. Princeton University Press: Princeton, New Jersey. 2004; H. Raffles 2002; and Clifford, J. in his comments in a February 20, 2008 lecture at UC Berkeley. Clifford, and possibly Tsing, draw on Stuart Hall's (via Althusser and Marx) notion of articulation. Stuart
} 
In applying political ecology analyses to indigenous communities, there is, first, an issue with terminology. The very concept of "natural resources" itself-the "ecology" of political ecology-is imbricated within a particular understanding of other beings and human-environment interaction. ${ }^{12}$ Poststructural political ecology has emphasized this social construction in definitions of ecology, resources, and environmental issues, creating room for multiple dialogues on different understandings of place. ${ }^{122}$ This article has touched on the ways in which indigenous communities in rural California are struggling with neocolonial constructions of nature, and political-economic institutions that constrain and regulate their ability to interact with natural resources. ${ }^{123}$ Constraints upon indigenous stewardship affect different members of the community differently, depending not only upon their economic positionality (i.e., as landowners or not), but also upon their epistemological and cosmological positionality, which may not vary predictably with the former, and which defines how individuals see themselves in relation to the environment. Because many Maidu are not landowning, and many were denied the opportunity to learn cultural knowledge because of the boarding school process that forced their parents and grandparents to stop practicing and passing it on, if they now undertake traditional land stewardship, it is on the social, epistemological, and political margins of both Maidu and American society. ${ }^{124}$

A useful link between the coloniality and the political ecology approaches to understanding power and access to natural resources is the concept of "articulation," from Stuart Hall. ${ }^{125}$ Articulation refers to the joining together of different elements, in part to foreground particular identities. Anthropologist and political ecologist Tania Murray Li has looked at the formation of movements based on articulations of land claims with terms of identity, such as "indigenous." ${ }^{126}$ This allows for an exploration of how the classification of "indigenous" is perceived and utilized, and therefore speaks to the politics of inclusion and representation always inherent in movement building, including the types of tools activists use to convey claims and build support.

Practices of decolonization and healing that involve re-acquiring and re-naming places, for example, face the questions of, what exactly is being re-acquired, and by and for whom? Both the initial colonial taking, and the indigenous re-claiming involve far more than re-organizing physical resources. What is at stake-and this is the central factor in internal Maidu and external (i.e., with potential supporters or detractors) disputes about the reclaiming - are the meanings given to resources, ethnicity, and community. Within the broad confines of an "indigenous" framework, acknowledging that vast differences exist

Hall discusses the connections between race and identity, as intertwined with power ("Race, Articulation, and Societies Structured in Dominance" 38-68 in P.Essed and D.T. Goldberg, (eds.) Critical Race Theories: Text and Context. Wiley-Blackwell Publishers. 2001). In his 2008 Berkeley lecture, Clifford used articulation to argue against essentialist notions of "disappeared cultures," arguing instead that Native cultures can change and still be Native cultures.

${ }^{121}$ See Blaikie, P. 1985 and Blaikie, P. \& H. Brookfield 1987 for early discussion of the issue of soil erosion, as the ecological factor that could be most productively understood through complementary and simultaneous political and economic analysis. These authors defined the field by putting what had theretofore been understood as a purely ecological problem in conversation with political, economic, and social drivers and reactions. Later, Watts showed how the local limits of ecology, and/or the ecological characteristics of harvesting a certain resource, such as oil, also interact significantly and iteratively with international social, political, and economic factors (Watts, M.J. Economies of Violence: More Oil, More Blood. Economic and Political Weekly 38 (48): 5089-5099. 2003.). As the field came to emphasize political, economic, and social field methods, Zimmerer argued for enhancing the inclusion of ecology in political ecology by undertaking more scientific studies that are then placed in dialogue with sociological, political, and economic examinations of political economy (Zimmerer, K. and T. Bassett. "Approaching Political Ecology: Society, Nature, and Scale in Human-Environment Studies," 1-27 in Political Ecology: An Integrative Approach to Geography and Environment-Development Studies. Guilford Press: New York. 2003).

122 See, for example, Brosius, P. "Endangered Forest, Endangered People: Environmentalist Representations of Indigenous Knowledge." Human Ecology 25(1): 1997; and Kosek, J. "Deep Roots and Long Shadows." Environment and Planning D: Society and Space. 22:329-354. 2004.

${ }^{123}$ For example, as Robert Paton writes, "The bitter irony is that indigenous people throughout the world have sophisticated knowledge of the intricacies of nature, but are all too often the first victims of programs that propose to protect the land." Paton, Robert J. "Back into the Park: California Desert Protection Act offers hope to Timbisha Shoshone." News from Native California 8(4): 50-51. Spring 1995; for a book-length argument regarding the importance of Native American interaction with and tending of California natural resources, see, for example, Anderson, M. K. Tending the Wild: Native American Knowledge and the Management of California's Natural Resources. University of California Press: Berkeley, CA. 2005.

${ }^{124}$ Many people were taught and remember important pieces of a coherent system of ecosystem knowledge. As one Maidu man said at a community meeting, "Everyone has a piece of the (cultural) knowledge — no one has everything." April 6, 2006.

125 S. Hall, in P. Essed and D.T. Goldberg 2002.

${ }^{126}$ Li, T.M. "Articulating Indigenous Identity in Indonesia: Resource Politics and the Tribal Slot." Comparative Studies in Society and History. 42(1): 149-179. 2000; and "Masyarakat Adat, difference, and the limits of recognition in Indonesia's forest zone." Modern Asian Studies 35(3): 645-676. July, 2001. See also Brosius, P. 1999; and Brosius, P. "Endangered forest, endangered People: environmentalist representations of Indigenous Knowledge." Human Ecology 25(1): 47-69. 1997. 
between and even within indigenous groups, the relationships between people and their homeland are central to that group's identity and worldview. ${ }^{127}$ These relationships transcend generations and invaders, and are interwoven with spiritual, political, economic, and cultural perspectives. Critical anthropologist James Clifford has been one of the few non-Native anthropologists speaking to political ecology to recognize the importance of this, and to note that articulation theory, as used by Hall and $\mathrm{Li}$, must be adapted:

Articulation theory, which sees everything as potentially realigned, cut and mixed, has difficulty with this material nexus of continuity. When a community has been living on an island for more than 1000 years, its not enough to say that their claims to identity with a place are historical strategies of opposition and coalition in struggles with neighbors, with colonizing or worldsystemic forces....I've found that when importing the work of Stuart Hall, Paul Gilroy, or Avtar Brah into the Pacific I've been made sharply aware of the...histories that lie behind it. There needs to be a significant adaptation to a different space. ${ }^{128}$

This reflection is empowering because Clifford indicates how articulation theory can be used proactively, to recognize tribal identity, for example, as well as noting the ways in which articulation does not work in an indigenous context, which has different conditions of possibility (such as relationship to place) than a non-indigenous context (where the conditions of possibility are seen as primarily political-economic). ${ }^{129}$ Clifford recognizes the specific non-indigenous roots of articulation and other theories that are erroneously applied by political ecologists and anthropologists to indigenous people.

\section{Conclusion: a political ecology of healing}

Scholarship within the broad field of political ecology is important for understanding natural resource-political economic formations, particularly the ways in which communities resist state organization of natural resources and political economy. However, in order to better understand humanenvironment interactions in historically colonized communities, elements of the political ecology approach much be combined with literature addressing intergenerational trauma survival and healing, particularly from indigenous perspectives, and the coloniality of power approach from ethnic studies. There can be the seeds of healing in recognizing the effects of history, and in simultaneously acknowledging and investing in cultural, political, economic, and spiritual decolonization. As the Summit attempts to unite different political entities within Maidu country, it is a consciously decolonial institution. The Council, for its part, is also making an effort to work with the Summit, and its individual members, but its premise of divesting PG\&E land without explicitly acknowledging the relationship of the divestiture process to the history of the taking of that very land from the ancestors of Summit participants, and the related lack of a social justice Beneficial Public Value, do not make the Council's process a decolonial one. Without perspectives from the coloniality of power and intergenerational trauma/healing, political ecology would not be able to speak to the colonial and de-colonial processes within Maidu country. It would also be in danger of imposing European-derived questions and explanatory frameworks on non-European contexts.

The theoretical ideas presented in this article attempt to provide a framework for understanding activism, governance, and resource policy in contemporary, rural indigenous communities that have survived a colonial history and continue to survive a neo-colonial present. Scholars drawing on this pluralistic approach will look at multiple scales to understand both the context and meaning of a certain resource; examine the influence of historic and ongoing colonization on present configurations of privilege; explore their own loci of enunciation; and consider the deep and abiding impacts that historic and contemporary colonialism have had on the psyche of a people, and, hence their governance, and how these impacts relate to simultaneous efforts to heal and to de-colonize.

I drew on the example of the Maidu Summit's efforts to get a seat at the table in the Stewardship Council's disposition of their culturally important properties. This illustrated how working to change contemporary policies that reproduce inequalities is a lengthy and multi-scalar process, which may be better explored with the concepts of trauma/healing and coloniality of power/de-coloniality. The latter make political ecology a more relevant and inclusive approach to natural resource issues in historically colonized/traumatized communities. As such, I propose a political ecology of healing.

\footnotetext{
127 See, for example, V. Deloria, Jr. 1994; L. Tuhiwai Smith 1999; Ruppel, Kristin T. Unearthing Indian Land: Living with the Legacies of Allotment. University of Arizona Press: Tucson, Arizona. 2008; LaDuke 2005; Wood, Mary Christina and Zachary Welcker. "Tribes as Trustees Again (Part I): The Emerging Tribal Role in the Conservation Trust Movement." Harvard Environmental Law Journal: 32, Spring 2008.

${ }^{128}$ Clifford, J. On the Edges of Anthropology (Interviews). Prickly Paradigm Press: Chicago. 2003: 91.

${ }^{129}$ See, for example, Hall, Stuart A. "The Problem of Ideology: Marxism Without Guarantees," 57-84 in B. Matthews, (ed.), Marx: 100 Years On. Lawrence and Wishart: London. 1983.
} 


\section{References}

Adams, David Wallace.

1995. Education for extinction. Lawrence, KS: University Press of Kansas.

Allen, Chadwick.

2002 Blood narrative. Durham, NC: Duke University Press.

Anderson, M. Kat.

1994 "Prehistoric anthropogenic wildland burning by hunter-gatherer societies in the temperate regions - a net source, sink, or neutral to the Global Carbon Budget." Chemosphere 29 (5): 913934.

- 1999. "The fire, pruning, and coppice management of temperate ecosystems for basketry material by California Indian tribes." Human Ecology 27 (1): 79-113.

- 2005. Tending the wild: Native American knowledge and the management of California's natural resources. Berkeley: University of California Press.

Bates, Karen Grigsby.

2004. "Alvin Ailey's dance troupe at 45." National Public Radio: May 27.

Bateson, G.

1972. Steps to an ecology of mind: collected essays in anthropology, psychiatry, evolution, and epistemology. University of Chicago Press.

"Biggest Power Plant in World for Plumas County."

Plumas National Bulletin. Vol. 45, No. 96: July 27, 1911.

Bill, Eli Peazzoni (Sus-424), and Emma Bill (Sus-426).

Case Files of Land Transactions, 1909-1956; Susanville; Records of the Bureau of Indian Affairs; Record Group 75; National Archives, Pacific Region (San Francisco), San Bruno, California.

Biolsi, Thomas, and Larry Zimmerman.

1997. Indians and anthropologists: Vine Deloria, Jr. and the critique of anthropology. University of Arizona Press.

Blaikie, Piers. 1985.

The political economy of soil erosion in developing countries. London: Longman Development Studies.

Blaikie, Piers. 1999. "A Review of Political Ecology." Zeitschrift fur Wirtschaftsgeographie. Jg. 43.

Blaikie, Piers, and Harold Brookfield. (eds.)

1987. Land degradation and society. London: Longman Development Studies.

Borenstein, Steven.

2002. "The Trouble with Electricity Markets: Understanding California's Restructuring Disaster." Journal of Economic Perspectives. 16(1): 191-211.

Brave Heart, Maria Yellow Horse, and Lemyra DeBruyn.

1998. "The American Indian holocaust: healing historical unresolved grief." American Indian and Alaska Native Mental Health Research. Monograph series 8:2.

_ 2001. "Clinical interventions with American Indians," in R. Fong and S. Furuto, (eds.) Cultural competent social work practice: Practice skills, interventions, and evaluation. Massachusetts: Longman Publishers.

- 2005 Keynote address at the Fifth Annual White Bison Wellbriety Conference (transcript): Denver, Colorado. April 22.

Brosius, Peter.

1997. "Endangered Forest, Endangered People: Environmentalist Representations of Indigenous Knowledge." Human Ecology 25(1).

- 1999. "Green dots, pink hearts: displacing politics from the Malaysian rain rorest." American Anthropologist 101(1): 36-57.

Bryant, Ray.

1998. "Power, knowledge and political ecology in the third world: a review." Progress in Physical Geography 22 (1): 79-94.

Cajete, Gregory.

1999. Native science: natural laws of interdependence. Santa Fe, New Mexico: Clear Light Books. 
California Public Utilities Commission.

2003. "Stipulation Resolving Issues Regarding the Land Conservation Commitment." September 25, 2003; and California Public Utilities Commission. "Opinion Modifying the Proposed Settlement Agreement of PG\&E Company, PG\&E Corporation, and the Commission Staff, and Approving the Modified Settlement Agreement." December 18, 2003.

Cardoso, Fernando Henrique and Enzo Faletto.

1979. Dependency and Development in Latin America. Translated by Marjory Mattingly Urquidi. Berkeley: University of California Press.

Census

2000. Plumas County: Race and Ethnicity.

Churchill, Ward.

2004. Kill the Indian, save the man: the genocidal impact of American Indian residential schools. San Francisco, CA: City Lights Books.

Clifford, James.

2003. On the edges of anthropology (interviews). Chicago: Prickly Paradigm Press.

— 2008. Invited lecture: Department of Sociology, UC Berkeley. February 20, 2008.

Cornell, Steve., and J.P. Kalt, (eds.)

1992. What can tribes do? Strategies and institutions in American Indian economic development. University of California, Los Angeles: American Indian Studies Center.

- 1995. "Where does economic development really come from? Constitutional rule among the contemporary Sioux and Apache." Economic Inquiry 33(3): 402-426.

- 1998. "Sovereignty and nation-building: the development challenge in Indian country today." American Indian Culture and Research Journal 22(3): 187-214.

Craib, Raymond.

2004. Cartographic Mexico. Durham, NC: Duke University Press.

Cunningham, Farrell.

2007. Maidu Summit Land Management Plan. July.

- Personal communication: Greenville, CA. 2005, 2007.

— "Traditional ecology," in Feather River Country. Forthcoming.

Cunningham, Trina.

Personal communication: Greenville, CA. 2006-2008.

Deloria, Jr., Vine.

1988. "Anthropologists and other friends," in Custer died for your sins: an Indian manifesto. University of Oklahoma Press.

— 1994. God is red: a native view of religion. Golden, Colorado:.Fulcrum Publishing.

Dixon, Ronald Burrage.

1905. The Northern Maidu. American Museum of Natural History Bulletin 17(3). New York: Knicker-bocker Press.

DuBois, W.E.B.

1935. Black reconstruction in America: 1860-1880. New York: Harcourt Brace.

Duhl, Leonard J.

2002. Personal communication: Berkeley, California. Fall.

Duran, Eduardo.

2006. Healing the soul wound: counseling with American Indians and other native peoples. New York: Teachers College Press.

Dussel, Enrique.

1980. Philosophy of liberation. New York: Orbis Books.

Eng, David, and David Kazanjian, (eds.)

2003. Loss: The politics of mourning. Berkeley: University of California Press.

Fanon, Franz.

1963. The wretched of the Earth. New York: Grove Press. 
Fischer, Michael M. J., and George E. Marcus (eds.) 1986. Anthropology as cultural critique. Chicago: University of Chicago Press.

Fixico, Donald L. 1986. Termination and relocation: Federal Indian Policy 1945-1960. Albuquerque: University of New Mexico Press.

Freire, Paulo.

1970. Pedagogy of the oppressed. Continuum Books.

Getches, David H., Charles F. Wilkinson, and Robert A. Williams, Jr. 1988. Cases and materials on Federal Indian law. St. Paul, Minnesota: West Group.

Gezon, Lisa.

1997. "Political ecology and conflict in Ankarana, Madagascar." Ethnology 36(2): 85-100. — 1999. "Of Shrimps and Spirit Possession." American Anthropologist 101(1): 48-67.

Giles-Rankin, Juliann Elizabeth. 1983. An ethnohistorical reconstruction of the Greenville Indian Industrial School. Master's Thesis: California State University, Chico.

Gorbet, Lorena. 2006. Personal communication: Greenville, CA.

Gould, Janice. 1990. Beneath my heart. New York: Firebrand Books. — 1995. "American Indian women's poetry: strategies of rage and hope." Signs 20(4): 797-817.

Gramsci, Antonio. 1975. Prison notebooks, v.1. New York: Columbia University Press.

Great Western Power. Annual Report to Stockholders. 1922.

Greenville Rancheria. Enrollment Ordinance.

Grosfoguel, Ramón.

2007. "The epistemic decolonial turn." Cultural Studies 21(2): 211-223.

__2008. Personal communication: San Francisco, CA. February.

Gunder Frank, Andre.

1969. "The development of underdevelopment," in Latin America: underdevelopment or revolution. New York: Monthly Review Press.

Hajer, Maarten.

1995. The politics of environmental discourse. Oxford: Clarendon Press.

Hall, Stuart A.

1983. "The problem of ideology: Marxism without guarantees," pp57-84 in B. Matthews, (ed.) Marx: 100 Years On. London: Lawrence and Wishart.

__ 2001. "Race, articulation, and societies structured in dominance" pp38-68 in Philomena Essed and David Theo Goldberg, (eds.) Critical race theories: text and context. London: WileyBlackwell.

Haraway, Donna.

1991. "Situated knowledges," in Simians, cyborgs, and women: the reinvention of nature. London: Routledge.

Hecht, Susanna B.

1985. "Environment, development, and politics: capital accumulation and the livestock sector in Eastern Amazonia." World Development. 13 (6).

Heizer, Robert.

1966. Languages, territories, and names of California Indian Tribes. Berkeley: University of California Press.

Hoopes, C.

1975. Domesticate or exterminate: California Indian treaties unratified and made secret in 1852. Redwood Coast Publications. 
Hunt, Leigh Ann.

1996. Rite of spring: a history of the Mountain Maidu Bear Dance. Lassen County Historical Society.

Hymes, Dell, (ed.)

1999 (1972) Reinventing anthropology. Ann Arbor: University of Michigan Press.

Kosek, Jake.

2004. "Deep roots and long shadows." Environment and Planning D: Society and Space. 22: 329354.

Kottak, Conrad P.

1999. "The new ecological anthropology." American Anthropologist 101(1): 23-35.

Kroeber, Alfred L.

1925. Handbook of the Indians of California. Berkeley: California Book Company.

LaDuke, Winona.

1975. Recovering the sacred. Cambridge MA: South End Press.

Landon, Michael N. 1988.

Resource development in the Feather River basin: The creation of Lake Almanor. California State University, Sacramento: Master's Thesis.

LeBeau, Michelle. 1993.

"A Healing Process," Prized Writing 1992-1993, An Anthology from the University of California, reprinted in Frontiers: A Journal of Women's Studies, 23(2) (2002).

Lee, H. Rex, 1961.

letter to Representative Harold T. Johnson. April 3, 1961. Records of the Bureau of Indian Affairs; Record Group 75; National Archives: Washington, D.C.

Li, Tania Murray. 2000.

"Articulating indigenous identity in Indonesia: resource politics and the tribal slot." Comparative Studies in Society and History. 42(1): 149-179.

- 2001. "Masyarakat Adat, difference, and the limits of recognition in Indonesia's forest zone." Modern Asian Studies 35(3): 645-676.

Little, Jane Braxton.

2000. "Maidu Indians work to restore their land and culture. American News Service. July 20.

London, Jonathan.

2001. Placing conflict and collaboration in community forestry. PhD Dissertation: University of California, Berkeley.

Maldonado-Torres, Nelson.

2007. "On the coloniality of being." Cultural Studies 21(2): 240 -270.

Manlove, Robert.

2003. "The Mountain Maidu Bear Dance." News from Native California 22(3).

Martinez, Dennis.

N.d. "The Wisdom of Fire." Growing Native Newsletter.

Marx, Karl.

1977 (1867). Capital: a critique of political economy. Volume 1. Translated by Ben Fowkes. New York: Vintage Books.

Middleton, Beth Rose.

2007-2008. "Mercury in our water, our fish, and our people: raising awareness." News from Native California. 21(2): Winter.

- 2008. We were here, we are here, we will always be here. a political ecology of healing in Mountain Maidu Country. Ph.D dissertation, University of California, Berkeley, 2008.

Mignolo, Walter.

2000. Local histories, global designs. Princeton: Princeton University Press.

- 2002. "The geopolitics of knowledge and the colonial difference." South Atlantic Quarterly 101(1).

- 2007. "Delinking: the rhetoric of modernity, the logic of coloniality, and the grammar of decoloniality." Cultural Studies. 21(2): 449-514. 
Momaday, N. Scott.

1968. House made of dawn. New York: Harper and Row.

Moraga, Sherrie, and Gloria Anzaldúa, (eds.).

1984. This bridge called my back: writings by radical women of color. Kitchen Table: Women of Color Press.

Myers, Joe.

2003. Personal communication. Berkeley, California. October.

Nebelkopf, Ethan and Mary Phillips, (eds.).

2004. Healing and mental health for Native Americans: speaking in red. Walnut Creek: AltaMira Press.

North Fork Associates.

2006. Dyer Mountain Resort: Recirculated Draft EIR. July.

"Opinion Modifying the Proposed Settlement Agreement of PG\&E Company, PG\&E Corporation and the Commission Staff, and Approving the Modified Settlement Agreement."

2003. Decision 03-12-035. December 18, 2003, before the Public Utilities Commission of the State of California. Available at http://www.stewardshipcouncil.org. Site accessed June 10, 2008.

Paton, Robert J.

1995. "Back into the park: California Desert Protection Act offers hope to Timbisha Shoshone." News from Native California 8(4): 50-51.

Peet, Richard, and Watts, Michael. J.

1996. "Introduction," in Liberation Ecologies: Environment, Development, and Social Movements. $1^{\text {st }}$ edition. London: Routledge.

Peluso, Nancy Lee.

1994. Rich forests, poor people: resource control and resistance in Java. Berkeley: University of California Press.

Poka Leanui (Hayden F. Burgess).

2000. "Processes of decolonization," 150-160 in Marie Battiste, (ed.) Reclaiming Indigenous voice and vision. Vancouver: University of British Columbia Press.

Prucha, Francis Paul.

1994. American Indian Treaties. Berkeley: University of California Press.

Pyne, Stephen J.

1994. "Maintaining focus: an introduction to anthropogenic fire." Chemosphere 29 (5): 889-911.

Quijano, Anibal.

1992. "Colonialidad y modernidad-racionalidad," and "Colonialidad del poder" 437-47 in Heraclio Bonilla, comp. (Bogotá Tercer Mundo Editores), Los Conquistados: 1492 y la Población Indígena de las Américas.

Quijano, Anibal.

2000. "Coloniality of power, eurocentrism, and Latin America." Nepantla 1(3): 533-80.

Rabinow, Paul. 1977. Reflections of fieldwork in Morocco. Berkeley: University of California Press.

Raffles, Hugh.

2002. In Amazonia: a natural history. Princeton, NJ: Princeton University Press.

Ramirez, Reyna.

1998. "Healing through grief: urban Indians reimagining culture and community in San Jose, California." American Indian Culture and Research Journal 22(4): 308.

Rappaport, Roy A.

1967. "Ritual regulation of environmental relations among a New Guinea people," in Andrew Vayda, ed., Environment and cultural behavior: ecological studies in cultural anthropology. Garden City NJ: The Natural History Press.

Riddell, Fritz.

1978. "Maidu and Concow," in Heizer, Robert F., ed. Handbook of North American Indians, Vol. 8, California. Washington D.C.: Smithsonian Institution. 
Romm, Jeff.

2002. "The coincidental order of environmental justice," in Kathryn Mutz, Gary Bryner, and Douglas Benner, (eds.) Justice and natural resources: concepts, strategies, and applications. Washington D.C.: Island Press.

Ruppel, Kristin T. 2008. Unearthing Indian Land: living with the legacies of allotment. Tucson: University of Arizona Press.

San Diego State University.

"California Indians and their reservations." [Online reference].

Santa Clara Pueblo v. Martinez (436 U.S. 49, 98 S.Ct. 1670, 56 L.Ed.2d 106)

Schroeder, Richard A. 1997. "Re-claiming" land in the Gambia: Gendered property rights and environmental intervention." Annals of the Association of American Geographers 87 (3):487-508.

Siemerling, Winfried.

2005. The new North American studies: culture, writing, and the politics of re/cognition. Routledge: New York.

Silver, Steven M., and John P. Wilson.

1988. "Native American healing and purification rituals for war stress (337-355), in Wilson, John P., Zev Harel, and Boaz Kahana (eds.) Human adaptation to extreme stress: from the Holocaust to Vietnam. New York: Plenum Press.

Snodgrass, J, Lacy, MG, Sharma, SK, Jhala, YS, Advani, M, Bhargava, NK, Upadhyay, C.

2008. "Witch hunts, herbal healing, and discourses of indigenous ecodevelopment in North India: theory and method in the anthropology of environmentality." American Anthropologist 110(3): 299-312.

Stewardship Council Board of Directors. 2007. Land conservation plan. Volume 1: Section 2-1.

Tiller, Veronica E. Velarde. 2004 (1996). Tiller's Guide to Indian Country. Albuquerque: BowArrow Publishing Company.

Tillie Hardwick et al. v. United States, Civil No. C-79-1910-SW (N.D. Cal. 1983).

Tsing, Anna.

2004. Friction: an ethnography of global connection. Princeton NJ: Princeton University Press.

Tuhiwai Smith, Linda.

1999. Decolonizing methodologies. London: Zed Books.

United States Department of the Interior

letter to Herbert Young. March 25, 1960. Greenville; Central California Agency; Records of the Bureau of Indian Affairs; Record Group 75; National Archives, Pacific Region [San Francisco], San Bruno, California.

United States Forest Service.

2003. Maidu Stewardship Area landscape analysis: 1-1, 2, 3. October.

— 2007. Special Forest Products Rule. FR Vo. 72, No 203, Doc E 7-200658. October 22.

Valey, Nicholas N.

1986. History of Feather River Canyon.

Vandergeest, Peter, and Nancy Lee Peluso.

1995. "Territorialization and state power in Thailand." Theory and Society 24(3): 385-426.

Wallerstein, Immanuel.

1979. The capitalist world-economy. Cambridge University Press.

__2001. "The inventions of timespace realities: towards an understanding of our historical systems," (135-148) in Unthinking social science: the limits of $19^{\text {th }}$ century paradigms. Philadelphia: Temple University Press.

Watts, Michael J.

2000. "Political ecology," in T. Barnes and E. Sheppard (eds.) A companion to economic geography. Oxford: Blackwell. 
__2003. Economies of violence: more oil, more blood. Economic and Political Weekly 38 (48): 5089-5099.

Warne, William E.

letter to Hugh Butler. February 20, 1948. Slagle, Al Logan. Collection. D-437. University of California, Davis. Shields Library, Department of Special Collections. Box 45.

West, M. Kate.

2005. "Indian Rancheria says that curtain will destroy heritage" and "Thermal curtain breaks graves law, says Rancheria." Feather River Bulletin, August 17.

Williams, Robert A.

2006. "Why are some Native Nations more successful than others?" Lecture: September 26, 2006. University of California, Berkeley.

Winichakul, Thongchai.

1997. Siam Mapped. University of Hawaii Press.

Wood, Mary Christina and Zachary Welcker.

2008. "Tribes as trustees again (Part I): the emerging tribal role in the conservation trust movement." Harvard Environmental Law Journal: 32, Spring.

Woodcock, D.W., and P.V. Wells.

1994. "The burning of the new world. the extent and significance of broadcast burning by early humans." Chemosphere 29 (5): 935-948.

Zimmerer, Karl and Tom Bassett.

2003. "Approaching political ecology: society, nature, and scale in human-environment studies." pp1-27 in their Political ecology: an integrative approach to geography and environmentdevelopment studies. New York: Guilford Press. 


\begin{abstract}
Political ecology has expanded in multiple new directions since Piers Blaikie's explanation of the manifestations of political economy and ecology in the "problem" of soil erosion in the 1980s. In this article, I try to extend political ecology to engage with ethnic studies literature on coloniality, and indigenous perspectives on intergenerational trauma and healing. Drawing on historic and contemporary examples of Maidu governance and resource development in the Maidu homeland, California, USA, I extend the concept of intergenerational trauma in Native American communities from the individual and ethnic group levels to include the community's relationship with the land, and the concept of itself as a sovereign civic, governing body. I place specific manifestations of trauma, de-colonizing, and healing, as exemplified by Maidu natural resource activism, in dialogue with political ecology approaches to better understand the relationships between historically colonized people, governance, and land. I argue that the relationships between people and resources that political ecology focuses on cannot be adequately understood in historically colonized communities dealing with neo-colonial resource and political policies, without attention to perspectives on coloniality/de-coloniality, and trauma/healing. These perspectives come from both survivors of colonialism, and from ethnic studies and indigeneity scholars.
\end{abstract}

Key words: political ecology, coloniality, Maidu, trauma, healing, Native American

\title{
Resumen
}

Desde que Piers Blaikie explicó la importancia de combinar la economía política y ecología para explicar el "problema" de la degradación del suelo, la ecología política se ha expandido en múltiples direcciones. En este articulo combino la ecología política con las áreas de derechos ambientales, epistemologías, y la historia ambiental, a través de un dialogo entre estudios étnicos sobre colonialidad y perspectivas indígenas sobre trauma intergeneracional y curación. Para ello, utilizo ejemplos históricos y actuales de cómo los Maidu de California, USA gobiernan y desarrollan a sus recursos naturales, extendiendo el concepto de trauma intergeneracional para discutir la relación entre comunidad y tierra, y la formación de la consciencia de que el pueblo Maidu es un grupo soberano. Así mismo analizo, desde la ecología política, manifestaciones de trauma y curación encontrados en el activismo Maidu, para explicar a un nivel más general las relaciones entre tierra, gobernanza y descolonización.

Palabras clave: ecología política, colonialidad, Maidu, trauma, curación, nativos americanos

\section{Résumé}

"Political ecology" a augmenté dans de multiples directions de nouveau depuis les explications de Piers Blaikie de l'érosion des sols dans les années 1980. J'encourage l'approche d'examiner aussi les droits environnementaux, de l'épistémologie, et l'économie politique historique. "Political ecologists" doivent apprendre à partir d'études ethniques et colonialité. Je tire sur des exemples du développement des ressources et gouvernance dans la patrie Maidu, Californie, USA. La notion de traumatisme intergénérationnel dans les communautés amérindiennes est pertinente pour les individus, ainsi que pour la relation de la communauté avec la terre. Je discute aussi des réflexions de la communauté Maidu sur son rôle en tant que souverain, institution d'administration. L'étude des traumatismes et la guérison nous aider à comprendre les souffrances d'un peuple historiquement colonisés et leur retrait de terres coutumières. La documentation pertinente qui "political ecology", doit prendre en compte vient de survivants du colonialisme, et d'études ethniques et de l'indigénéité.

Mots clés: écologie politique, la colonialité, Maidu, traumatisme, guérison, Native American 